\title{
The significance of Upper Cretaceous hardgrounds and other discontinuity surfaces for basin-wide correlations, based on drillcore data from boreholes in northern Poland
}

\author{
Krzysztof LESZCZYŃSKI ${ }^{1}$ *
}

1 Polish Geological Institute - National Research Institute, Rakowiecka 4, 00-975 Warszawa, Poland

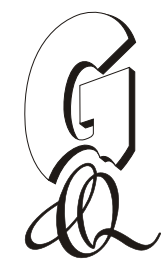

\begin{abstract}
Leszczyński, K., 2017. The significance of Upper Cretaceous hardgrounds and other discontinuity surfaces for basin-wide correlations, based on drillcore data from boreholes in northern Poland. Geological Quarterly, 61 (4): 825-844, doi: 10.7306/gq.1375

The paper presents the hardgrounds and some other correlative discontinuity surfaces found in Upper Cretaceous (Cenomanian-Maastrichtian) borehole sections of northern Poland. They were briefly described, and depositional environment was identified for both the underlying deposit (UD) and the overlying deposit (OD). The significance of these features for both basin-wide correlations and broadly understood sequence stratigraphic techniques is highlighted. They were correlated with other major discontinuity surfaces identified in boreholes of northern Poland in both drill cores and well logs if such identification was reliable based on geophysical borehole data. All these discontinuity surfaces were referred to the boundaries of the individual depositional cycles determined within the Upper Cretaceous succession: K3-II/K3-III, K3-III/K3-IV, K3-IV/K4-I, K3-IV/K4-II, K4-I/K4-II (or II or IV or V), K4-III/K4-IV (or V), K4-IVa/K4-IVb, probably K4-IVb/K4-V, and K4-V/Pc-I. The discontinuity surfaces can be related to both sea level fluctuations and tectonic activity during the Subhercynian phases. Most of them developed in relatively calm sedimentary conditions, outside the central part of the Mid-Polish Trough. The exceptions are three hardgrounds from the Człopa-Szamotuły Zone, which seem to be associated mainly with the Late Cretaceous tectonic (including salt tectonics) activity of this zone. The most common UD/OD configuration of sedimentary environments is the open-marine carbonate shelf both beneath and above the discontinuity surface. The second most common situation is the open-marine carbonate shelf beneath and the open-marine shelf with carbonate-siliceous sedimentation above. The gaps at the surfaces span variously long intervals, ranging from short periods (spanning a fraction of a depositional cycle) to long periods (comprising one or more depositional cycles). The position of the discontinuity surfaces facilitates searching for any possible hiatuses in the sections of other boreholes, and paying attention to local changes in sediment distribution patterns, and local tectonic activity.
\end{abstract}

Key words: Upper Cretaceous, discontinuity surface, hardground, basin-wide correlation, northern Poland.

\section{INTRODUCTION}

Research on both present-day and ancient depositional environments have resulted in the identification of various types of discontinuity surfaces (e.g., Goldring and Kaźmierczak, 1974; Bromley, 1975; Kennedy and Garrison, 1975; Seilacher, 1981; Clari et al., 1995), which can be manifested by bedding planes that are very important features in the sedimentary succession. They reflect a change in the conditions of sedimentation and are often related to gaps in the sedimentary record. A discontinuity surface is commonly defined as a surface that separates younger from older sedimentary rocks where geometric, sedimentological, diagenetic, or biostratigraphic criteria enable to infer a break in sedimentation.

\section{*E-mail: krzysztof.leszczynski@pgi.gov.pl}

Received: March 2, 2017; accepted: June 30, 2017; first published online: August 24, 2017
A specific kind of discontinuity surface is a hardground, very common in carbonate sequences. Hardgrounds are synsedimentarily lithified carbonate seafloors, exposed for a significant period, that become hardened in situ by the precipitation of carbonate cement in primary pore spaces (Wilson and Palmer, 1992).

Hardgrounds are often bored and/or encrusted with varied fauna well adapted for hard-substrate living. They are commonly impregnated by iron oxides, glauconite and phosphorites. In many regions, hardground surfaces are traced over large areas, reflecting uniform sedimentary conditions (Bromley and Gale, 1982). A comprehensive summary of knowledge on hardgrounds is given in Flügel (2004).

The use of hardgrounds and other discontinuity surfaces and their significance for the Cretaceous stratigraphy are highlighted in many studies on the European Cretaceous basins, as they are common features in the carbonate/chalk sequences deposited under calcite sea and greenhouse climate conditions (e.g., Voigt et al., 2008). They are commonly interpreted as marking cycle boundaries in depositional sequences (e.g., Hancock, 1989; Witzke and Bunker, 1996; Mortimore et al., 1998), indicating a cyclic deposition of the carbonate succes- 
sion. Therefore, hardgrounds are important features in sequence stratigraphic analysis as boundaries of variously ranked sequences (e.g., Owen, 1996; Pandey et al., 2010).

Hardgrounds can be used to estimate both tectonic and eustatic sea level changes and are thought to mark the regressive troughs on sea level curves (Hancock, 1989), or to have been followed by transgression (James and Bone, 1991; Jones and Desrochers, 1992; Lehrmann and Goldhammer, 1999). Hancock (1989) used them for the identification of sea level changes during the Late Cretaceous in the British region. Considered to represent sequence boundaries, they were used in developing a stratigraphical framework for the Turonian Chalk succession of southern England (Gale, 1996).

In northern Germany and Denmark, hardground surfaces were found in the Maastrichtian section (cf. Herring et al., 1996; Ineson et al., 2006), in the Upper Turonian (Wiese and Kröger, 1998), and near the Cenomanian/Turonian boundary (Prauss, 2006 - hardground in the uppermost Cenomanian). Wilmsen (2003) used a sequence stratigraphic analysis in the study of the Cenomanian in northern Germany, identifying a number of hardgrounds in the succession and concluding the eustatic nature of most Cenomanian sea level variations. In the Subhercynian Cretaceous Basin, Voigt et al. (2004) report the presence of Upper Turonian/Middle Coniacian boundary hardground. A hardground near the Cenomanian/Turonian boundary is also known from the Lower Saxony Basin of northwestern Germany (at the top of the Plenus Bed) (Hilbrecht and Dahmer, 1994). Another hardground from the uppermost Cenomanian (below the Plenus Bed) is reported by Prauss (2006) at Wunstorf.

In Lithuania, hardgrounds are a characteristic feature of the Upper Turonian-Maastrichtian Mielupis Formation (Grigelis and Leszczyński, 1998).

Hardground surfaces were also found in the Upper Cretaceous deposits of southern Poland. In the NE margin of the Holy Cross Mts and the Miechów Trough (Fig. 1A), they were reported from the Cenomanian-Turonian part of the succession (Cieśliński, 1959; Marcinowski, 1974; Peryt, 1983; Walaszczyk, 1992; Dubicka and Machalski, 2017). An excellent example of formation of a composite hardground is described by Olszewska-Nejbert (2004) from the eastern margin of the Polish Jura Chain, north of Cracow. Krassowska $(1973,1986)$ identified a number of hardgrounds in the Maastrichtian section of boreholes from the Radom-Lublin region (Lublin Trough) (Fig. 1A). In northern Poland, hardgrounds are particularly common in boreholes drilled in the Gorzów Block and the adjacent zone of the Szczecin Trough (this area is also called the Szczecin-Gorzów Synclinorium; Karnkowski, 2010), in the eastern part of the Peribaltic Syneclise and in the Mazury Elevation (Fig. 1A).

The drill cores from boreholes of northern Poland also reveal the presence of other prominent discontinuity surfaces corresponding to the hardgrounds. Their identification is based on faunal (macrofauna, foraminifers) and sedimentological (rock types and nature of contact surface) evidence, supported by well log interpretations.

In this paper, the chronostratigraphy is based on comprehensive studies of Błaszkiewicz and Cieśliński (1979), Jaskowiak-Schoeneichowa (1981), Jaskowiak-Schoeneichowa and Krassowska (1983), and Błaszkiewicz (1997), including some modification with respect to the Turonian/Coniacian boundary (Leszczyński, 2002a). A preliminary sequence stratigraphic approach to the Upper Cretaceous succession in the Polish Lowlands, and the identification of sedimentary cyclicity as well as depositional systems and environments have been given by Leszczyński (1997a, b, 2010, 2012).

\section{MATERIAL AND METHODS}

All data referred to in this paper come from observation and description of drill cores from Upper Cretaceous boreholes drilled during the last decades in northern Poland. First, inventory of descriptions of drill cores from available publications, manuscripts of M. Jaskowiak-Schoeneichowa, and author's own observations was made in search for hardgrounds and other correlative discontinuity surfaces. The hardgrounds were then classified, and depositional environment was identified for both the underlying deposit (UD) and the overlying deposit (OD). They were also correlated with some other discontinuity surfaces identified in nearby boreholes in both drill cores and well logs, if such identification was reliable based on geophysical borehole data. Finally, the hardgrounds and the other discontinuity surfaces were referred to the boundaries of the individual depositional cycles determined in the Upper Cretaceous succession by Leszczyński (1997b, 2010, 2012, 2017). Some drill core intervals with the hardgrounds, which are still in a relatively good condition, have been photographed by K. Leszczyński in 2017. One photo was taken by $M$. Jaskowiak-Schoeneichowa at the early stage of drillcore logging. Data from thin section observations derive from manuscripts of M. Jaskowiak-Schoeneichowa, made available to the present author.

Unfortunately, most of the hardground surfaces are currently unavailable for direct study because either the drill core has been damaged and is incomplete, or it is lost and discarded. This is why, also the discrimination between burrows and borings, and the type of filling material (representing either UD or OD) is in most cases not possible. Thus, the descriptions of the hardgrounds can unfortunately lack some important information.

\section{UPPER CRETACEOUS HARDGROUNDS OF NORTHERN POLAND}

\section{GENERAL INFORMATION}

Despite fragmentary coring in the Upper Cretaceous sections, we are able to recognize a considerable number of hardgrounds in boreholes drilled across the Polish Lowlands. During detailed lithological logging of drill cores, JaskowiakSchoeneichowa (1972, 1973, 1974, 1978a, b, 1979, 1981; Jaskowiak-Schoeneichowa and Krassowska, 1983; Jaskowiak-Schoeneichowa and Leszczyński, 2014) and Leszczyński (2014) identified and described a number of hardgrounds in the Upper Cretaceous section of some boreholes from northern Poland. These boreholes are clustered mainly in two areas: (1) in northwestern Poland in the Gorzów Block and the adjacent zone of the Szczecin Trough, and (2) in northeastern Poland in the eastern part of the Peribaltic Syneclise and in the Mazury Elevation (Fig. 1A). There is also one hardground surface reported from the Płońsk 8 borehole in the Płock Trough (Jaskowiak-Schoeneichowa and Krassowska, 1983; LeszCzyński, 2017; Fig. 1A, B-6).

The Gorzów Block and the adjacent zone of the Szczecin Trough are located in the distal area of the epicontinental Mesozoic sedimentary basin of Poland, to the south-west of its most subsident, axial zone called the Mid-Polish Trough. The zone was inverted during and after the Late Cretaceous to form the Mid-Polish Swell (Dadlez et al., 1998; Wagner et al., 2002; Krzywiec, 2006; Vejbaek et al., 2010). During Late Cretaceous times, the Gorzów Block was an area of relatively quiescent tectonic conditions, dominated by carbonate sedimentation, espe- 


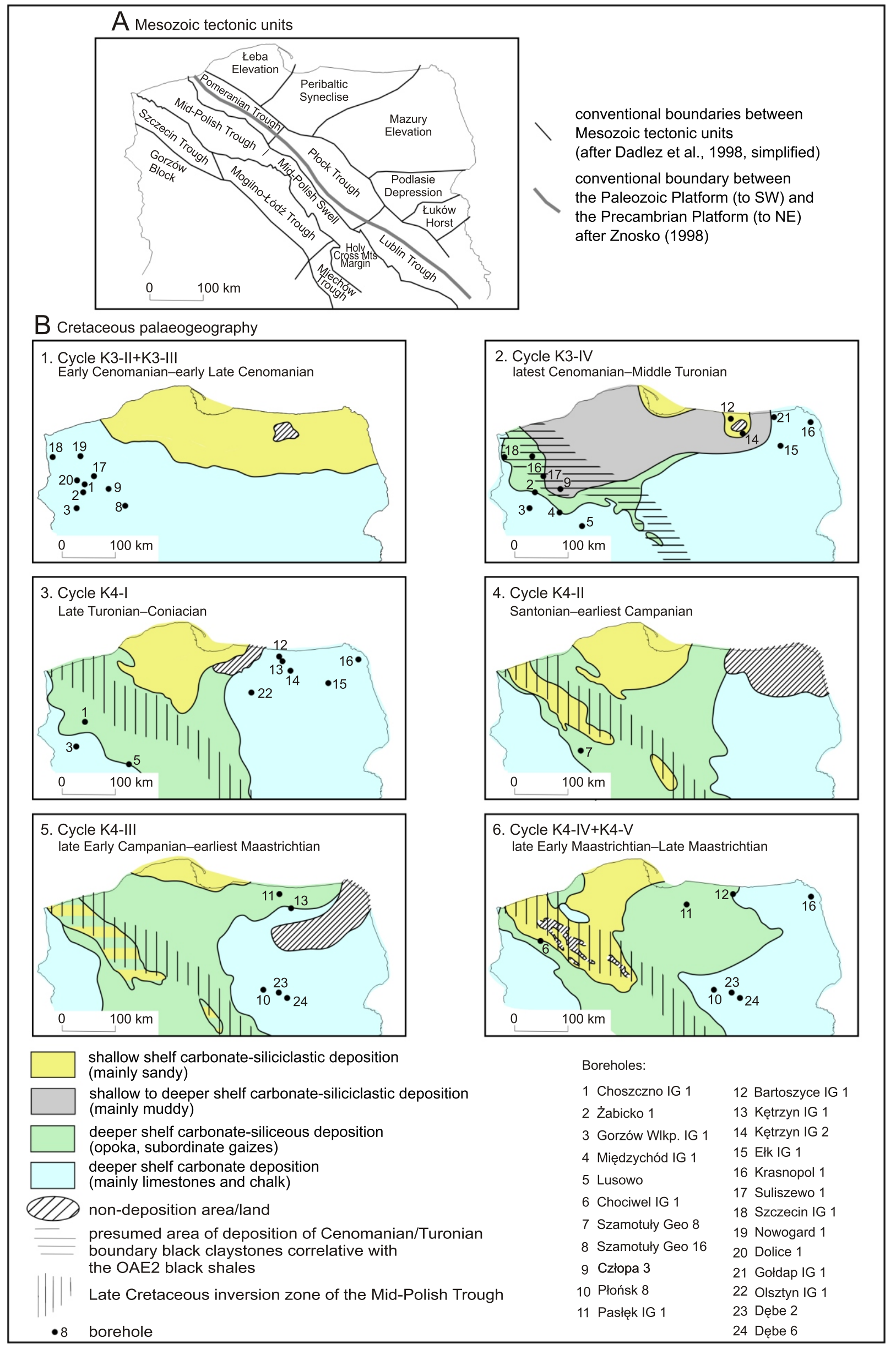

Fig. 1. Major Mesozoic tectonic units (A) and generalized Late Cretaceous palaeogeography (B) 
cially in its western part (Jaskowiak-Schoeneichowa, 1981; Leszczyński, 2010, 2012; Fig. 1B).

The Peribaltic Syneclise and Mazury Elevation are located on the other side of the Mid-Polish Trough/Swell on the Precambrian Platform area, also in a tectonically quiescent zone (Fig. 1A). However, there are a number of prominent gaps in the Upper Cretaceous section in this region, related to non-deposition periods due to bottom-current activity or weak and slow uplifting movements (Krassowska, 1997; Leszczyński, 2012; Fig. 1B). The Upper Cretaceous succession starts here with carbonate-siliciclastic, mostly sandy deposition to grade up into more muddy facies and, finally, into carbonate-siliceous and carbonate ones, including marls and chalk (Fig. 1B).

The Upper Cretaceous sections of northern Poland, in which hardgrounds are found, are composed predominantly of limestone, chalk, marl, opoka (siliceous marl) and non-sandy to moderately sandy gaize. The macrofaunal and foraminiferal determinations provided in Tables 1, 2 and 3, and thus the stratigraphic position of the hardgrounds and the other correlative discontinuity surfaces, are based on the results of micro- and macropalaeontological analyses, both published (Gawor-Biedowa, 1972, 1974, 1978, 2014a, b; Jaskowiak-Schoeneichowa, 1972 , 1973, 1974, 1978a, b, 1979, 1981; Witwicka, 1973; Cieśliński, 1974; Jaskowiak-Schoeneichowa and Krassowska, 1983; Jaskowiak-Schoeneichowa and Leszczyński, 2014) and those included as manuscripts in final reports of boreholes, stored at the NGA (National Geological Archives). A very important role was played by regional correlations of geophysical logs from many boreholes distributed over large areas of NW and NE Poland. Reference to the depositional cyclicity is based on author's own investigations (Leszczyński, 1997b, 2010, 2012).

The following hardgrounds have been identified in the Late Cretaceous sequence of northern Poland:

- Hardgrounds in Choszczno IG 1 and Żabicko 1 (Gorzów Block; Jaskowiak-Schoeneichowa, 1978b, 1981), which separate K3-III from K3-IV.

- Hardgrounds in Gorzów WIkp. IG 1 (Gorzów Block; Jaskowiak-Schoeneichowa, 1981; Jaskowiak-Schoeneichowa and Leszczyński, 2014), and Bartoszyce IG 1, Kętrzyn IG 2 and presumably Kętrzyn IG 1 (Peribaltic Syneclise; Jaskowiak-Schoeneichowa, 1974; Leszczyński, 2014), found between K3-IV and K4-I.

- Hardground in Międzychód IG 1 (Gorzów Block; Jaskowiak-Schoeneichowa, 1972), between K3-IV and K4-II.

- Hardground in Lusowo (Gorzów Block; Jaskowiak-Schoeneichowa, 1981), separating K4-I from K4-II.

- Hardground in Bartoszyce IG 1 (Peribaltic Syneclise; Jaskowiak-Schoeneichowa, 1974), between K4-III and $\mathrm{K} 4-\mathrm{IVb}(?)-\mathrm{K} 4-\mathrm{V}$

- Hardground in Płońsk 8 (Płock Trough; JaskowiakSchoeneichowa and Krassowska, 1983; Leszczyński, 2017), which separates K4-IVa from K4-IVb

- Hardground in Pasłęk IG 1 (Peribaltic Syneclise; Jaskowiak-Schoeneichowa, 1973), between K4-IVa and $\mathrm{K} 4-\mathrm{IVb}$.

- Hardgrounds in Kętrzyn IG 1 and IG 2 (Peribaltic Syneclise; Leszczyński, 2014), separating K4-I from K4-III, with a stratigraphic gap spanning K4-II.

- Hardground in Ełk IG 1 (Mazury Elevation; Jaskowiak-Schoeneichowa, unpublished materials), which separates K4-I from K4-IV, with a stratigraphic gap spanning a long time interval of K4-II and K4-III.
- Hardground in Krasnopol 1 (Mazury Elevation; Jaskowiak-Schoeneichowa, unpublished materials), between $\mathrm{K} 4-\mathrm{I}$ and $\mathrm{K} 4-\mathrm{V}$, with a stratigraphic gap also spanning a long time interval of K4-II, K4-III and K4-IV.

There are also hardgrounds in the Człopa-Szamotuły tectonic zone (Jaskowiak-Schoeneichowa, 1981), namely: an intra-K4-II hardground in Szamotuły Geo 8 (Szczecin Trough), and hardgrounds in Człopa 3 (Szczecin Trough - between K3-II and K3-III or less likely between K3-I and K3-II) and in Szamotuły Geo 16 (Szczecin Trough - also between K3-II and K3-III). All of them are most probably related to halotectonic activity in this salt-cored tectonic zone, although a combination of tectonic-eustatic factors cannot be excluded in these instances.

All the hardgrounds are briefly characterized below and their position in terms of stratigraphy and sedimentary environment is illustrated in Figure 2. They are roughly correlated with the sea level curve of Hancock (1989). For comparison, the recent curve of Haq (2014) is also drawn.

\section{SZCZECIN TROUGH AND GORZÓW BLOCK}

In the Gorzów Block and the neighbouring zone of the Szczecin Trough, hardground surfaces have been identified in the following boreholes: Choszczno IG 1, Żabicko 1, Gorzów Wielkopolski IG 1, Międzychód IG 1, Lusowo, Szamotuły Geo 8, Szamotuły Geo 16 and Człopa 3 (Fig. 1B and Table 1).

NE POLAND

In the Peribaltic Syneclise and Mazury Elevation, hardground surfaces have been identified in the following boreholes (Fig. 1B and Table 2): Pasłęk IG 1, Bartoszyce IG 1, Kętrzyn IG 1, Kętrzyn IG 2, Ełk IG 1 and Krasnopol 1. A discontinuity surface with no significant gap is interpreted in the Olsztyn IG 1 borehole. In the Płock Trough, a hardground surface was encountered in the Płońsk 8 borehole.

Another hardground is suggested to occur in the Kętrzyn IG 1 borehole (at $\sim 464.0$ m depth) between K3-IV and K4-I, which is interpreted from well log records, supported by the presence of the K3-IV/K4-I hardground documented at $598.5 \mathrm{~m}$ depth in the drill core from the Kętrzyn IG 2 borehole (see below). The UD is probably sandy limestone (open-marine siliciclastic-carbonate shelf), and the OD is chalk (open-marine carbonate shelf).

\section{OTHER CORRELATIVE DISCONTINUITY SURFACES}

In the Upper Cretaceous carbonate-dominated pelagic sequences, each sharp lithological boundary can be considered a discontinuity surface reflecting a shorter or longer break in sedimentation. Sedimentological investigations supported by microfaunal evidence allow recognition of a number of discontinuity surfaces that do not represent hardgrounds. Some of them may be defined as discontinuity surfaces incoherent at the moment of the renewal of sedimentation, at which part of the sedimentary record is missing, and referred to as omission surfaces.

Table 3 provides a summary of examples of some other prominent discontinuity surfaces correlative to the hardgrounds, identified in the drill cores from boreholes of northern Poland. 


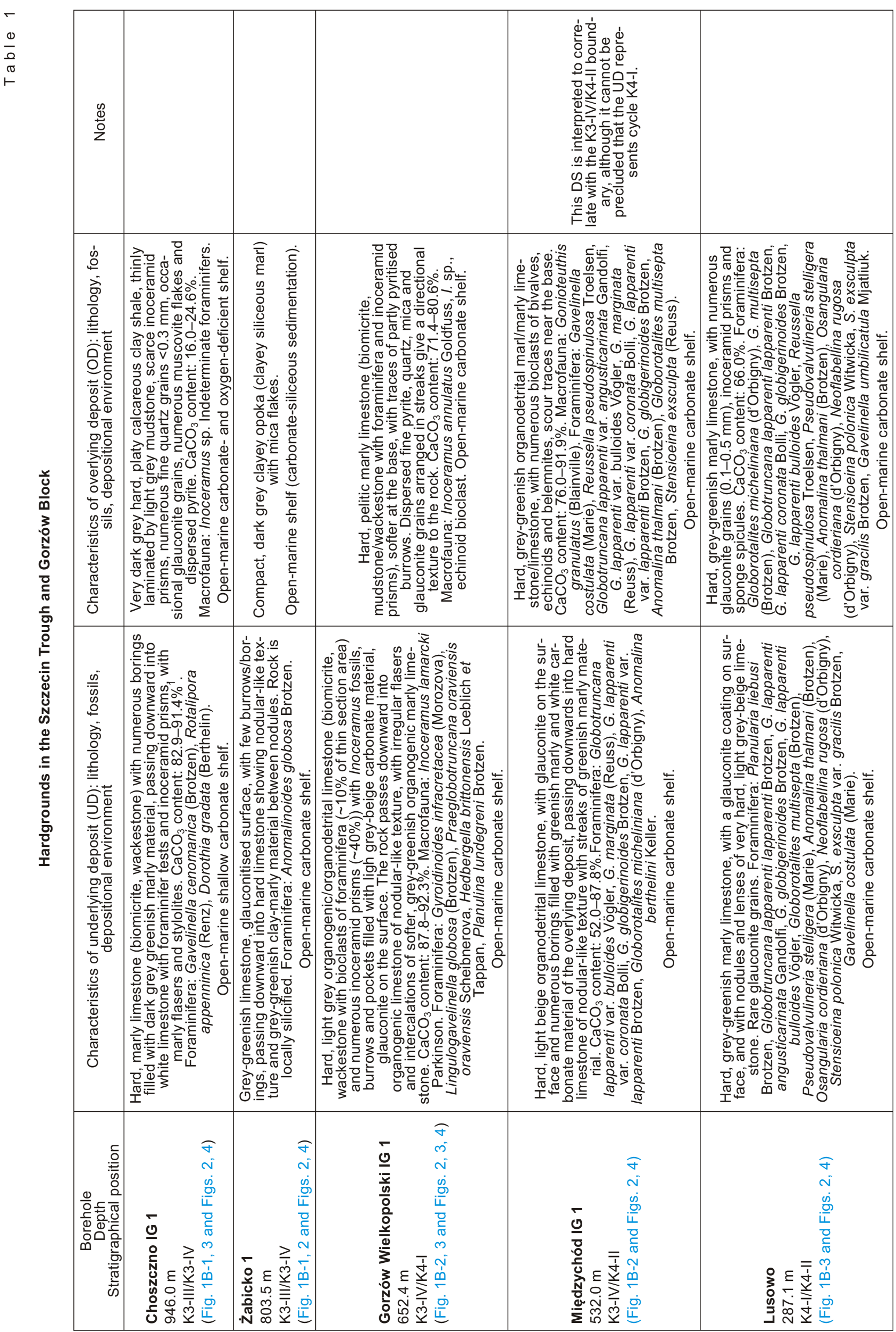




\begin{tabular}{|c|c|c|c|}
\hline $\begin{array}{l}\text { d) } \\
\frac{1}{2}\end{array}$ & 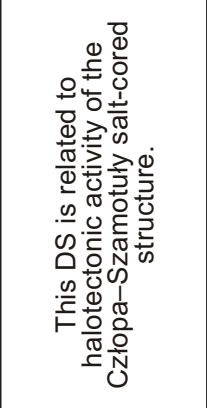 & 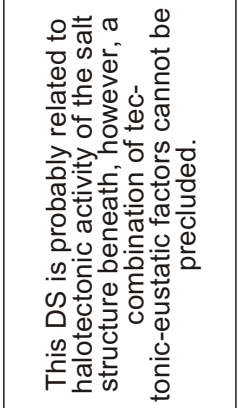 & 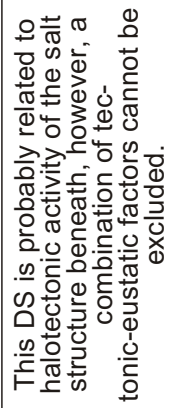 \\
\hline 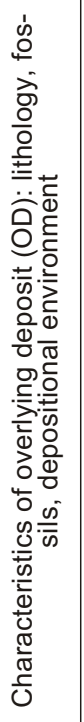 & 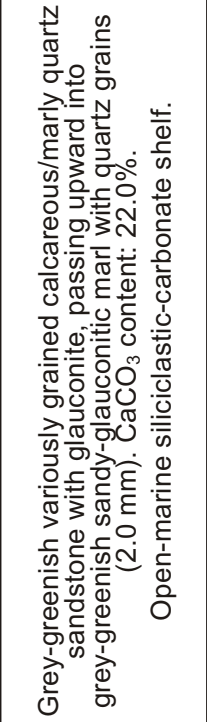 & 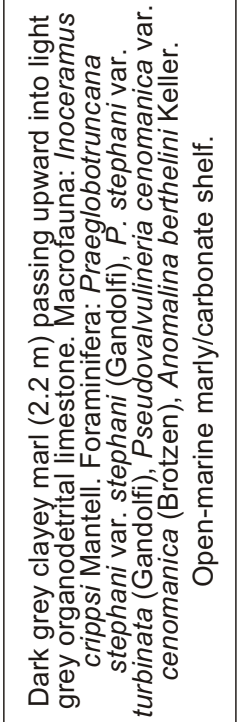 & 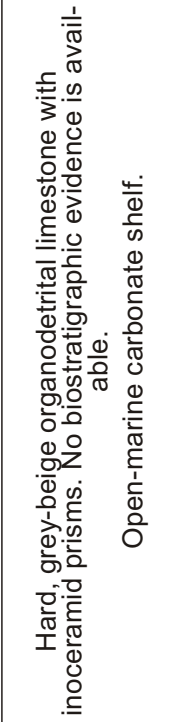 \\
\hline 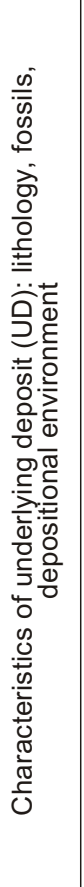 & 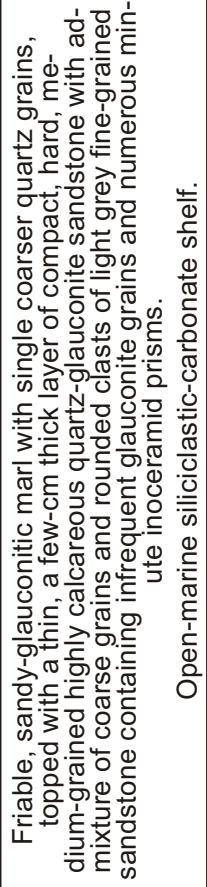 & 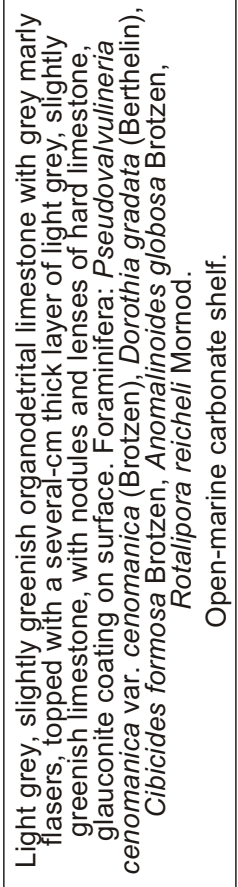 & 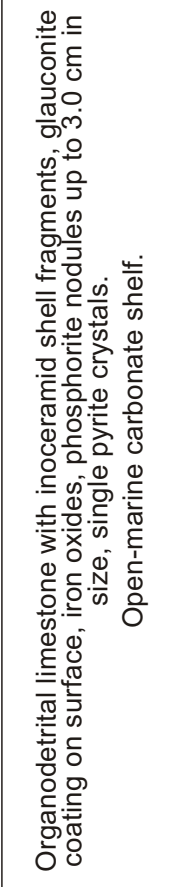 \\
\hline 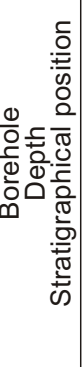 & 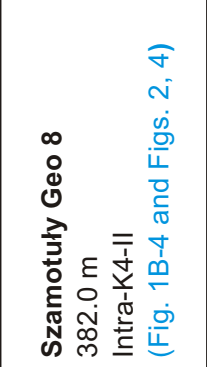 & 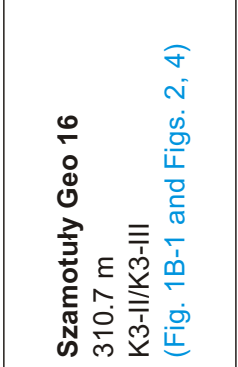 & 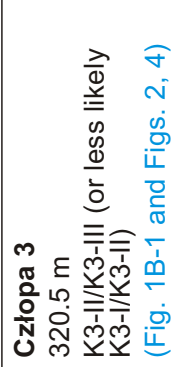 \\
\hline
\end{tabular}

\section{DISCUSSION}

It is usually interpreted that chalk was deposited in a relatively calm pelagic environment, and so were much of pelagic high- $\mathrm{CaCO}_{3}$ limestones and the so-called "chalk-like" limestones. Many open-marine carbonate settings, including those of the Cretaceous chalk sequences of Northwest Europe, contain numerous hardgrounds which can be traced over large distances. Widespread correlation of these hardgrounds across the basin may suggest allocyclic factors related to eustatic fluctuations. They represent intervals of highly reduced sedimentation rate, sediment starvation, or non-deposition, indicating breaks in sedimentation, e.g., due to a shallowing event, followed by a relative sea level rise and basin deepening. However, recent studies of pelagic chalk settings from the Danish area show also a possibility of highly dynamic depositional environment due to strong and long-living bottom currents which created highly diverse seafloor relief (Lykke-Andersen and Surlyk, 2004; Surlyk and Lykke-Andersen, 2007). The hardgrounds found in the Upper Cretaceous carbonate-dominated succession of NW and NE Poland developed in areas of relatively calm sedimentary-tectonic conditions, which may have been affected by bottom currents, although not as strong as those described by Lykke-Andersen and Surlyk (2004) as no broad valleys, ridges, channels, drifts and mounds are observed. However, there is also evidence for tectonic activity that may have influenced the formation of the hardgrounds.

Considering the presence of hardgrounds relative to tectonic zones, we can see that there are three cases of hardgrounds developed in the Człopa-Szamotuły Zone - a tectonically active area during the Late Cretaceous. These are: (1) mid-Santonian hardground found in the Szamotuły Geo 8 borehole, (2) mid-Cenomanian hardground from the Szamotuły Geo 16 borehole, and (3) the likely mid-Cenomanian hardground from the Człopa 3 borehole. They were undoubtedly associated with tectonic (including halokinetic) activity within this zone, correlated with the early stages of tectonic inversion of the Mid-Polish Trough and major tectonic zones in the Polish Basin (e.g., Leszczyński, 2000, 2002a, b; Krzywiec, 2006; Krzywiec et al., 2009). There is also possibility of a combination of bottom-current activity and sea level fluctuations (either of tectonic or eustatic origin, or both), which may have favoured the formation of hardgrounds, as evidenced by Eberli et al. (2010).

Moreover, some further comments should be made as regards the hardgrounds in the Człopa-Szamotuły Zone. Based on foraminiferal evidence and well log correlation, the Szamotuły Geo 16 hardground is interpreted to occur within the Cenomanian succession and is supposed to represent the K3-II/K3-III boundary. The Człopa 3 hardground likely represents the K3-II/K3-III boundary as well, although a K3-I/K3-II position (near the Upper Albian/Cenomanian boundary; cf. Jaskowiak-Schoeneichowa, 1981) cannot be excluded, as no clear fossil evidence is available. No distinct discontinuity surface has been recognized in this region, which could correspond to the K3-II/K3-III hardgrounds. However, a nodular limestone horizon has been reported from the middle part of the Cenomanian section in some boreholes, which can be correlated with the hardgrounds (cf. Hancock, 1989). As the formation of hardgrounds and other discontinuity surfaces in the Człopa-Szamotuły Zone was highly controlled by tectonic/halotectonic movements, they may not be straightforward age-equivalent to discontinuity surfaces in areas of low tectonic activity and thus to boundaries between the depositional cycles.

When analysing the lithology on both sides of the discontinuity surfaces we notice that most of the underlying deposits (UD) at the hardgrounds are limestones or chalk with some exceptions where the UD is represented by sandy marl topped 


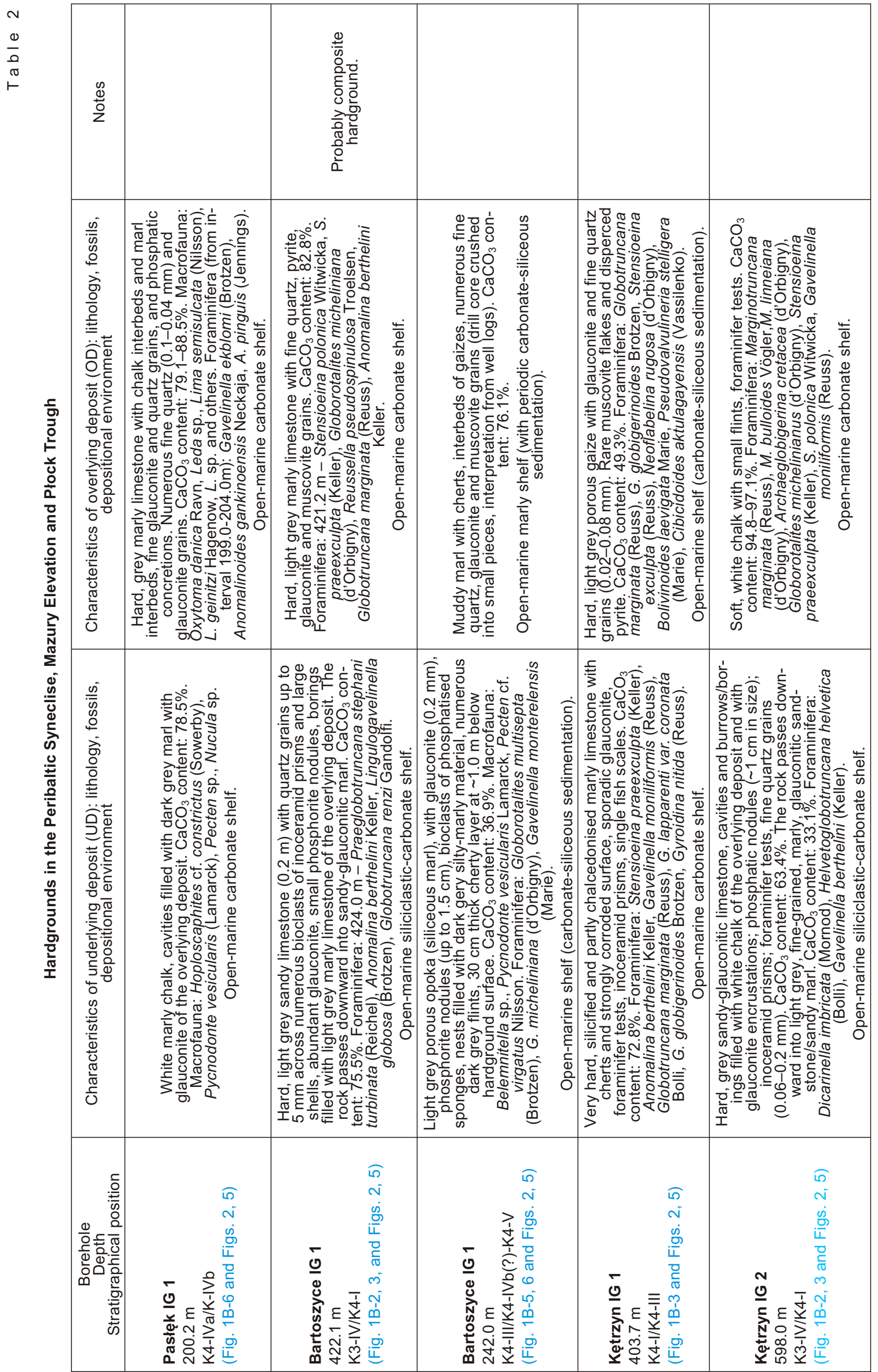




\begin{tabular}{|c|c|c|c|c|c|}
\hline 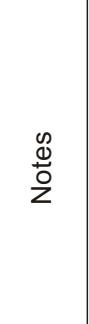 & & & 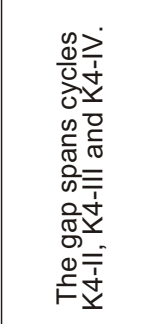 & & \\
\hline 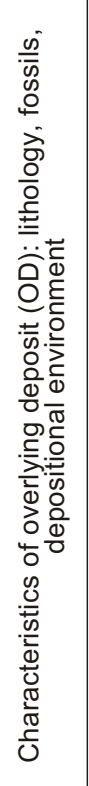 & 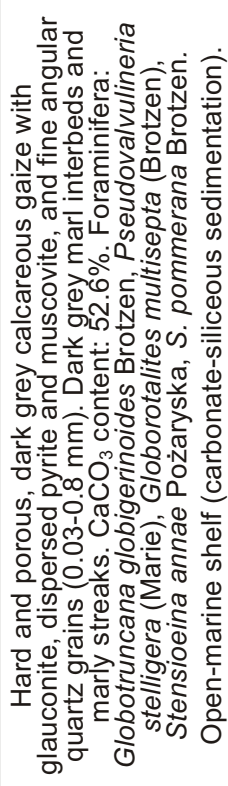 & 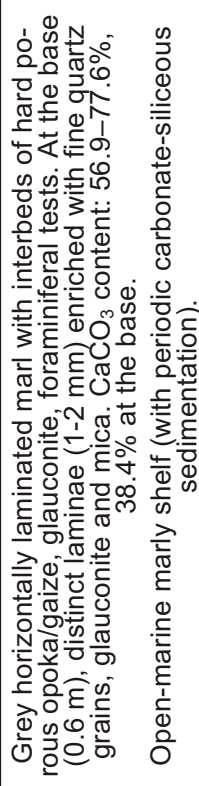 & 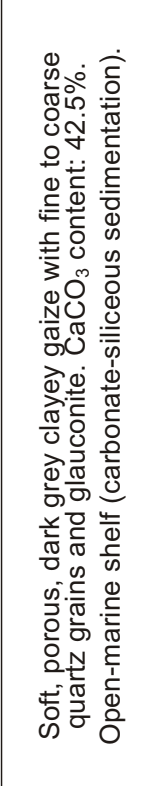 & 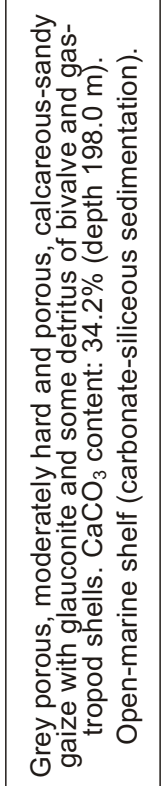 & 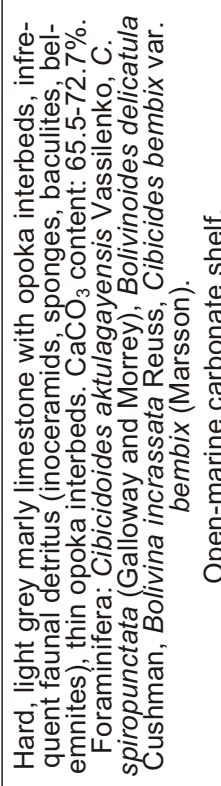 \\
\hline 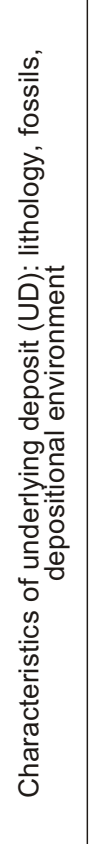 & 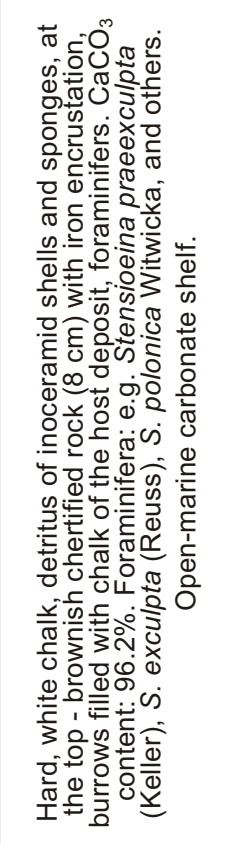 & 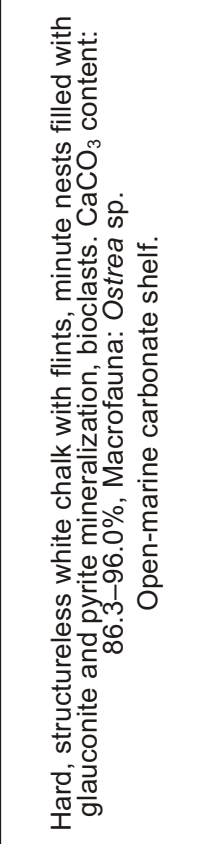 & 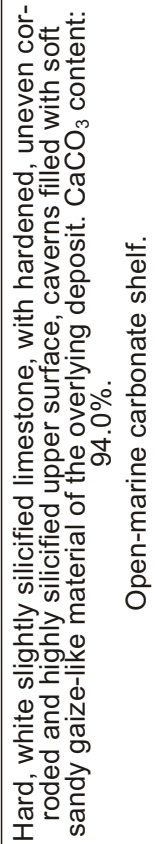 & 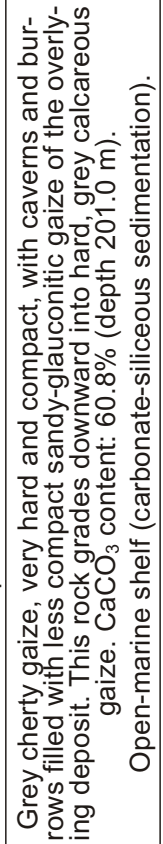 & 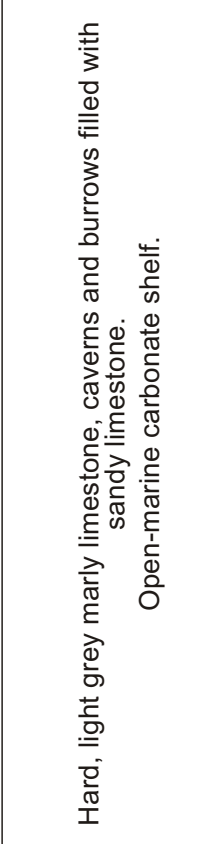 \\
\hline 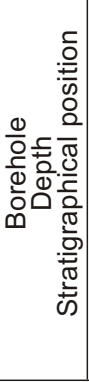 & 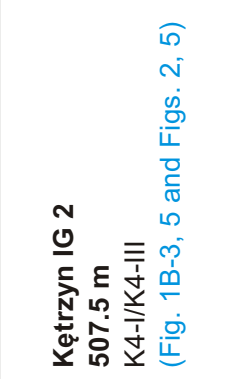 & 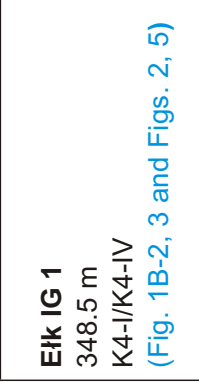 & 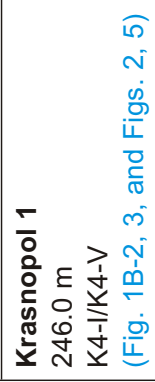 & 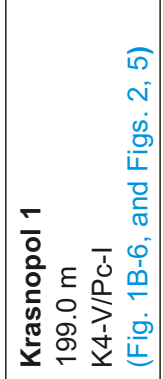 & 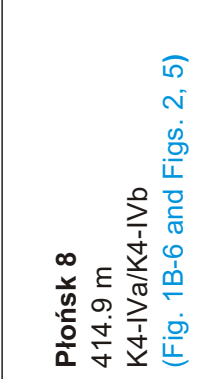 \\
\hline
\end{tabular}




\begin{tabular}{|c|c|c|c|c|c|c|c|c|c|c|c|}
\hline & 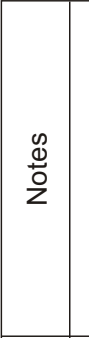 & & 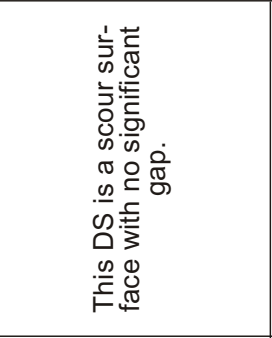 & & & 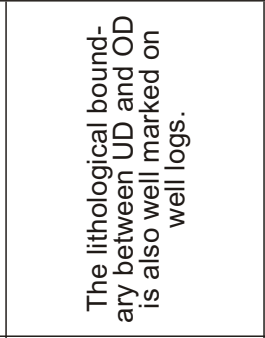 & & & & & 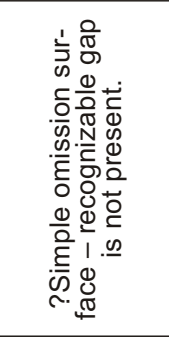 \\
\hline 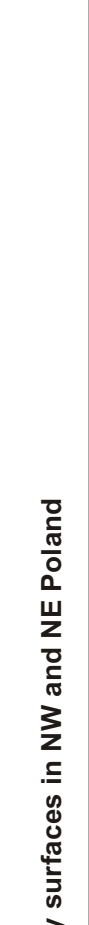 & 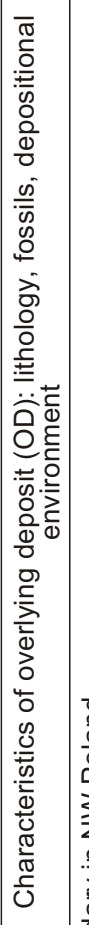 & & 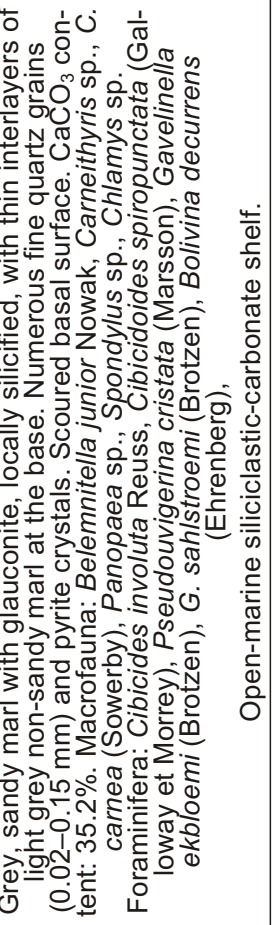 & 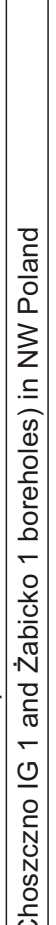 & 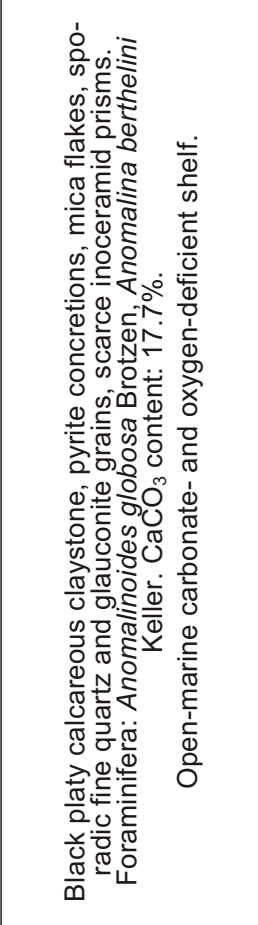 & 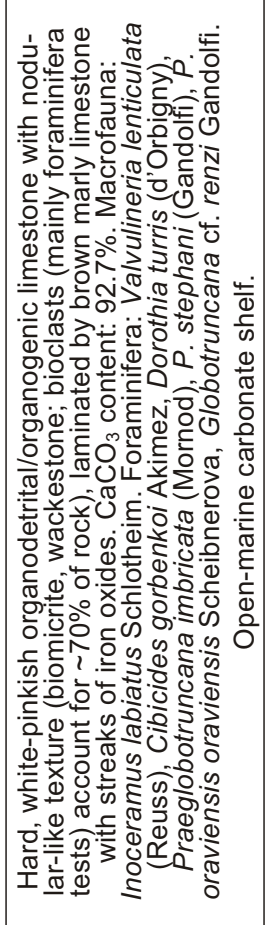 & 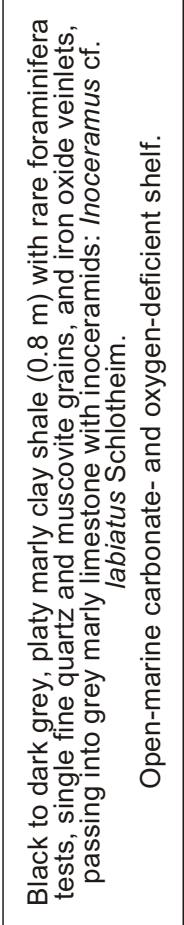 & 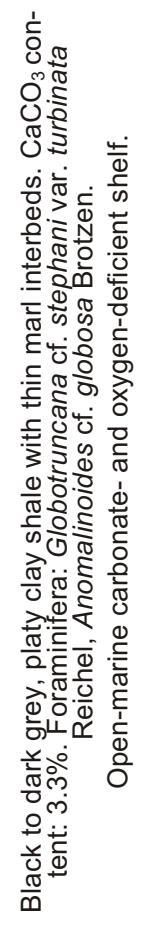 & 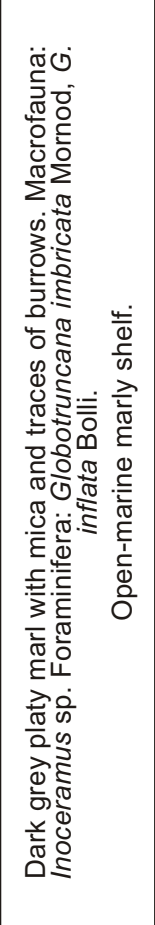 & 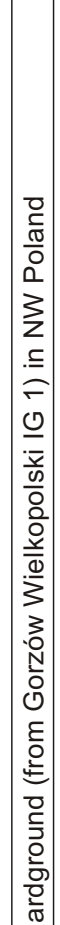 & 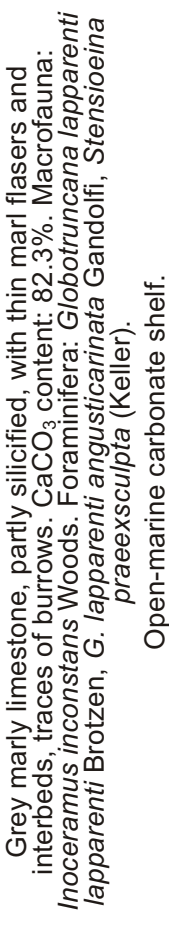 \\
\hline 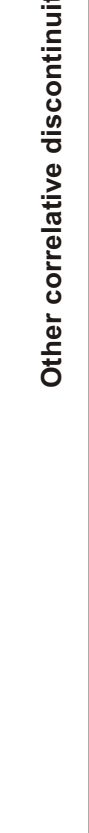 & 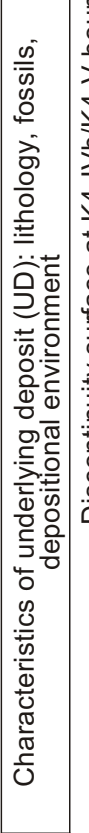 & 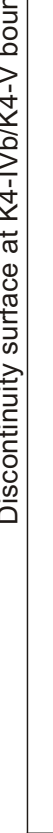 & 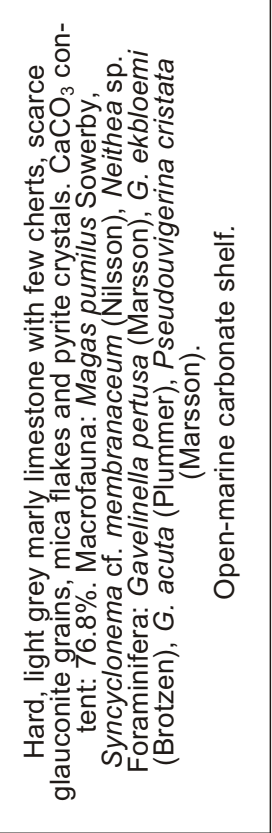 & 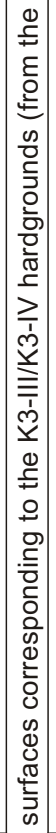 & 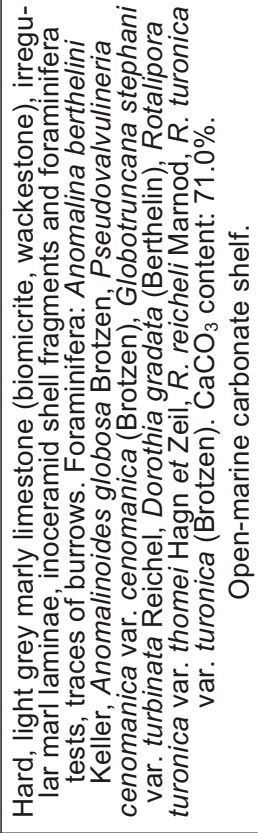 & 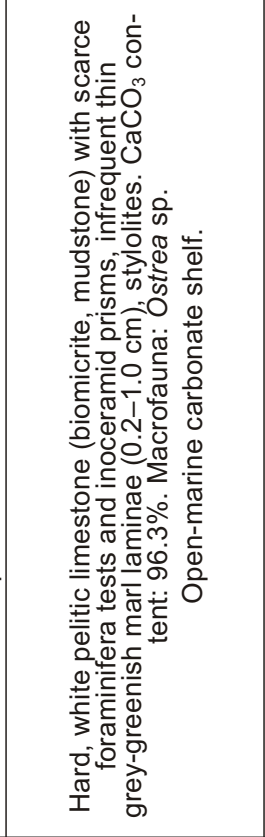 & 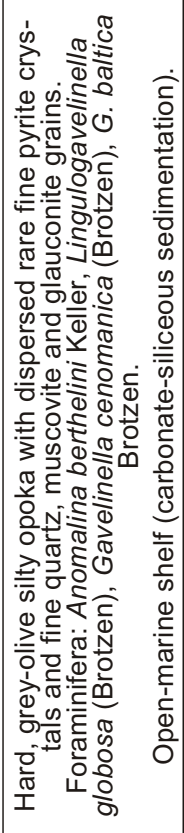 & 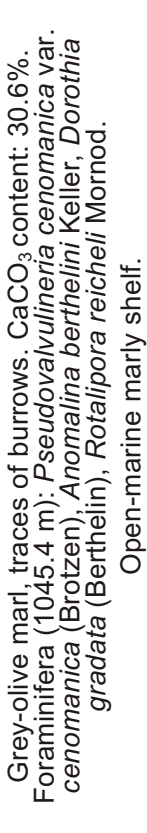 & 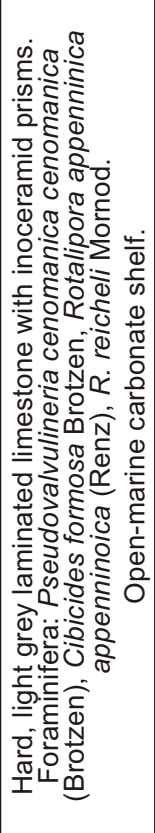 & 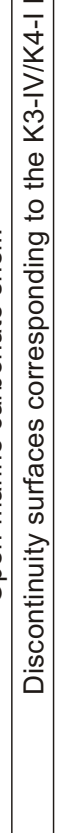 & 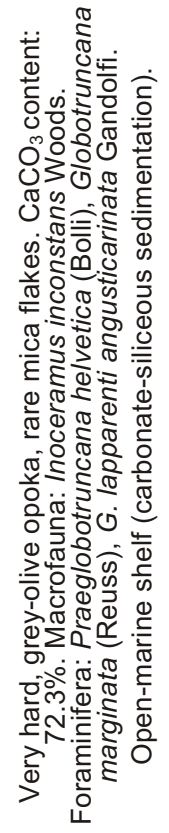 \\
\hline & 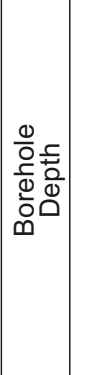 & & 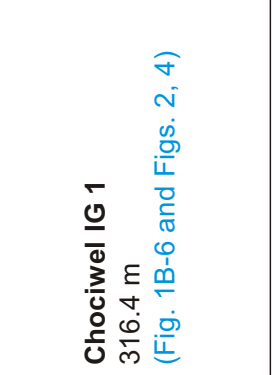 & & 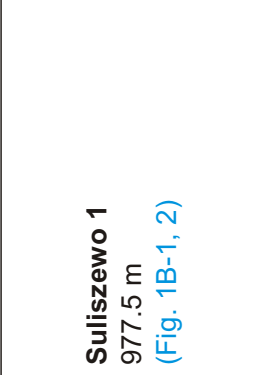 & 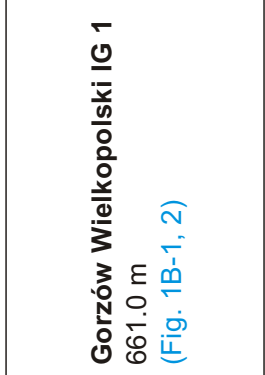 & 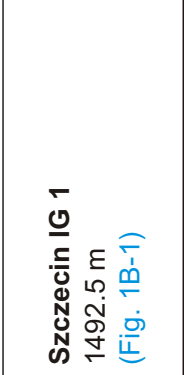 & 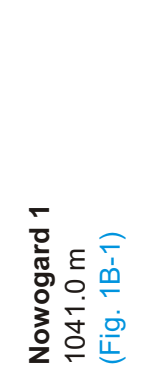 & 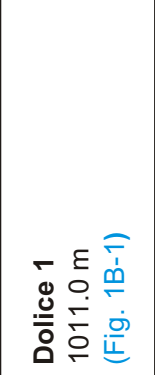 & & 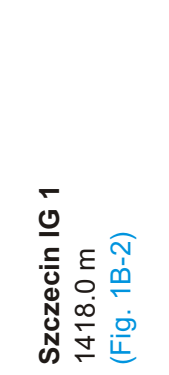 \\
\hline
\end{tabular}




\begin{tabular}{|c|c|c|c|c|c|c|c|c|c|c|}
\hline 总 & & & & \multirow{2}{*}{\multicolumn{2}{|c|}{ 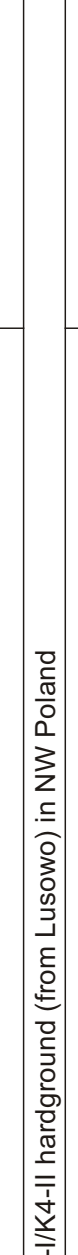 }} & & & & 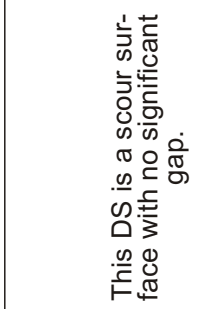 & \\
\hline 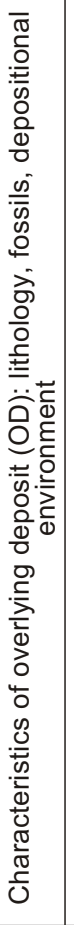 & 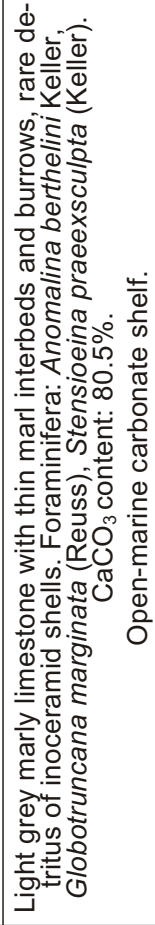 & 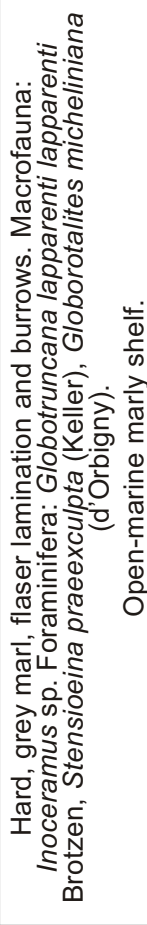 & 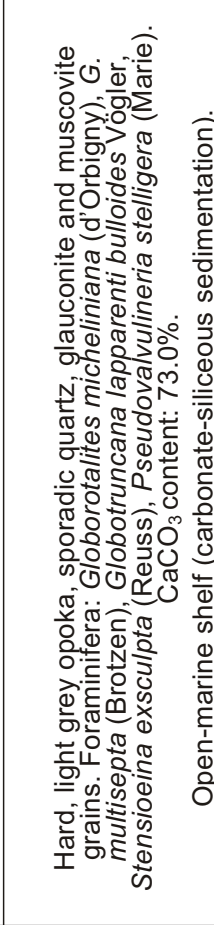 & & & 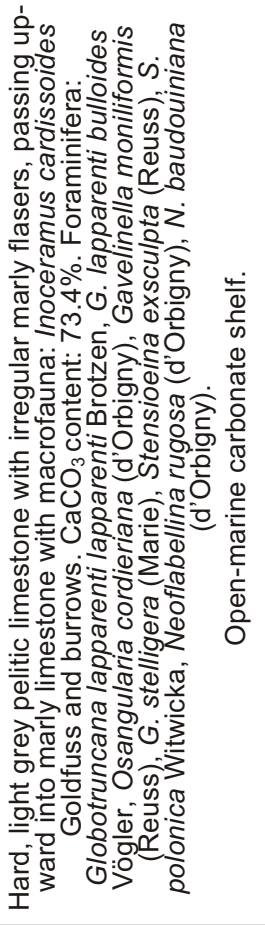 & 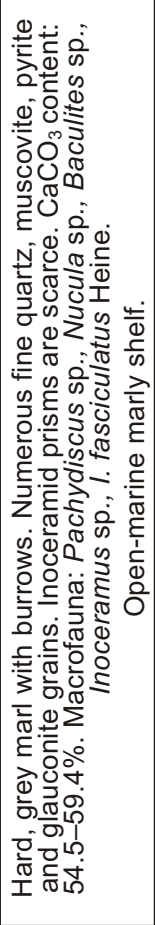 & 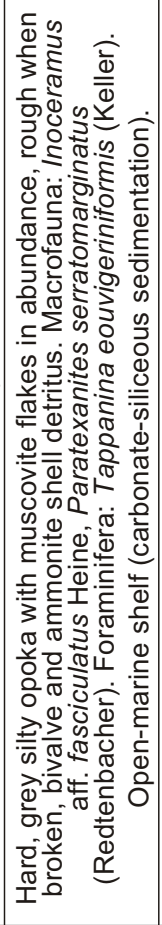 & 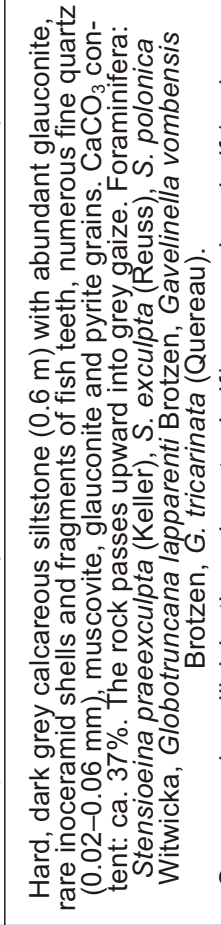 & 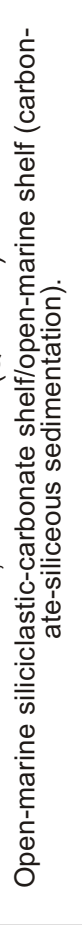 \\
\hline 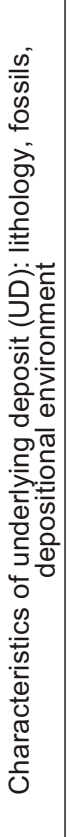 & 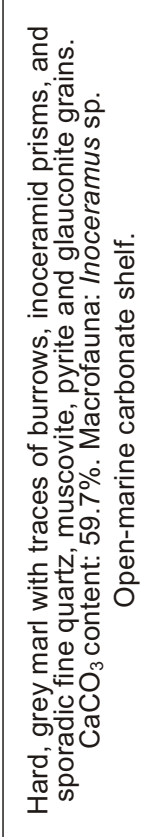 & 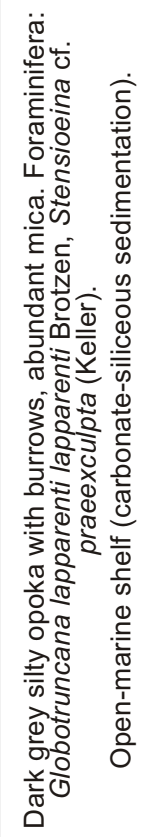 & 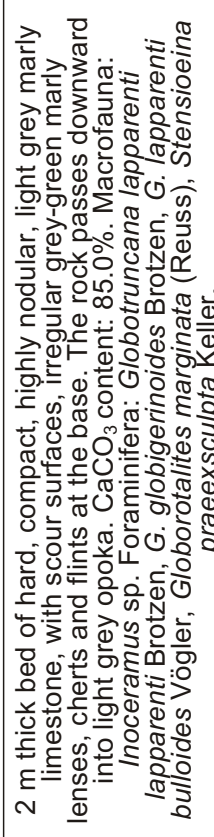 & 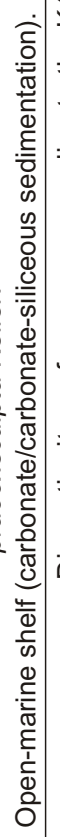 & & 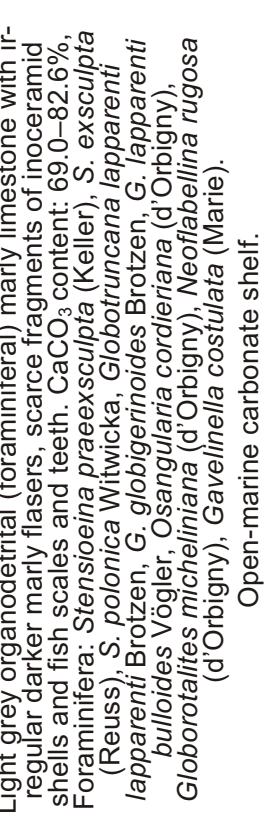 & 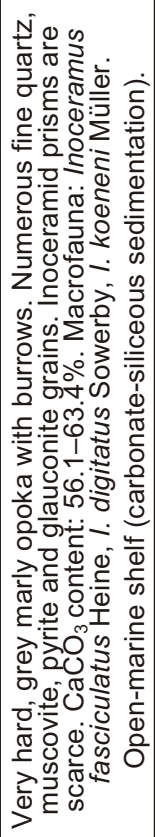 & 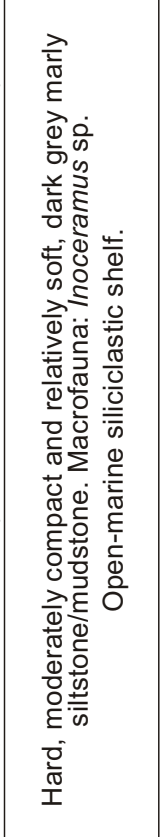 & 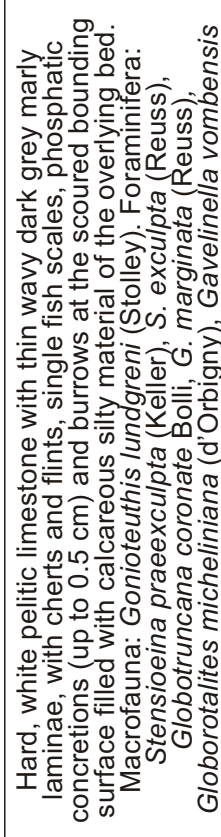 & 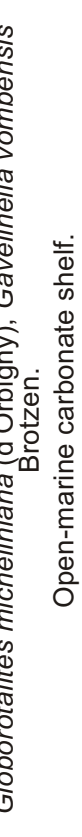 \\
\hline 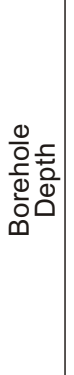 & 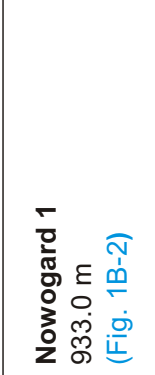 & 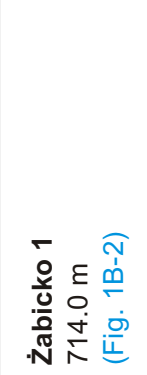 & 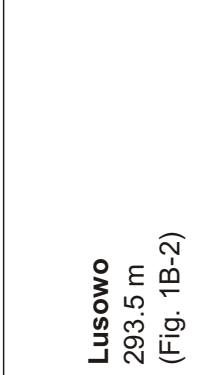 & & & 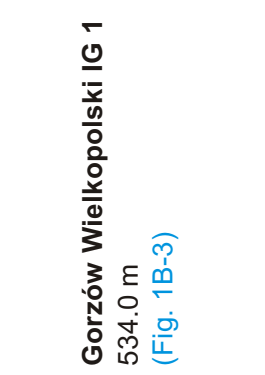 & 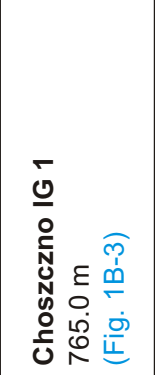 & 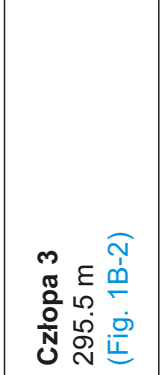 & 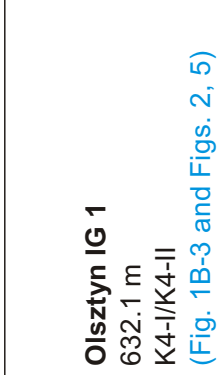 & \\
\hline
\end{tabular}




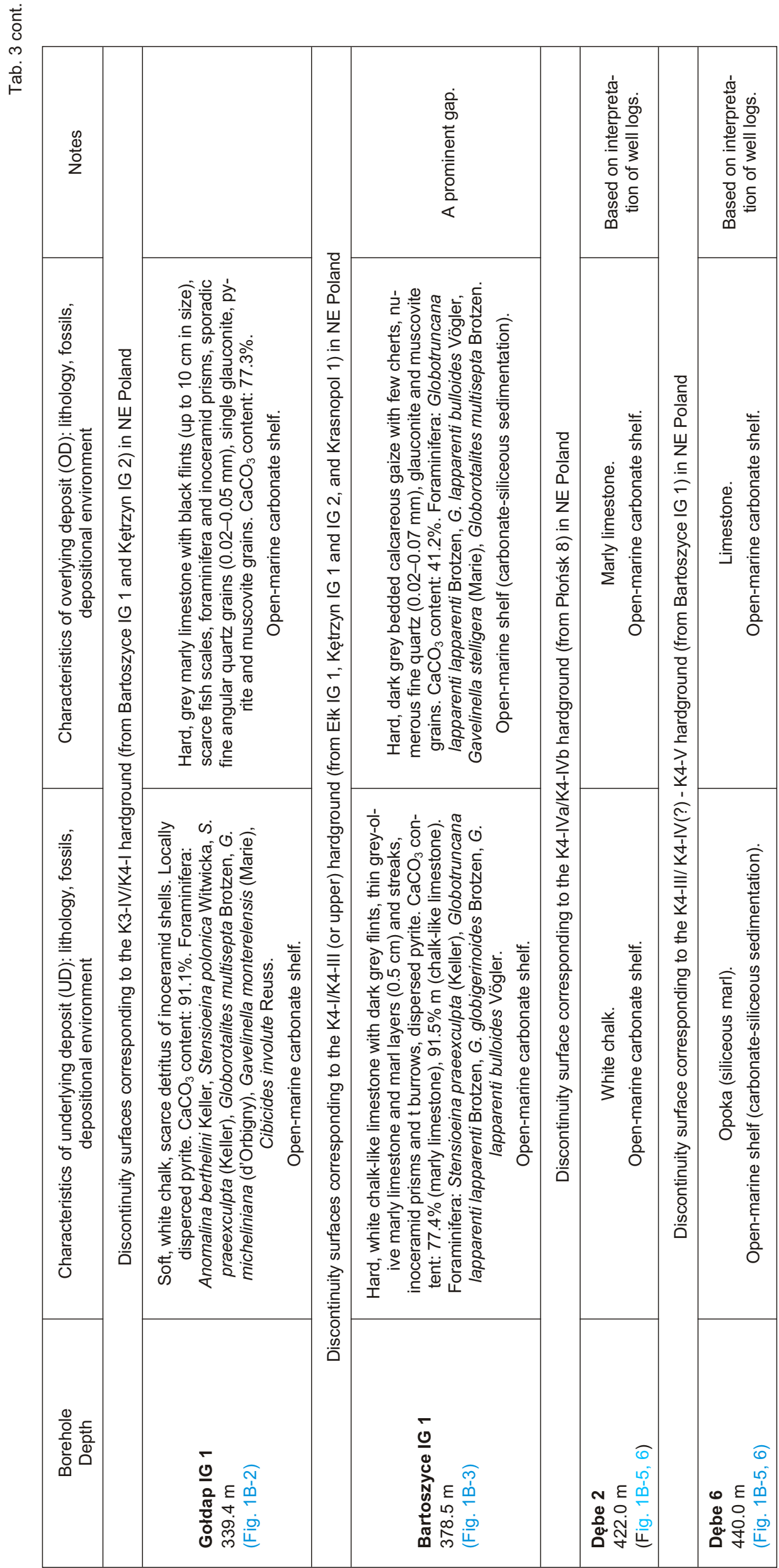




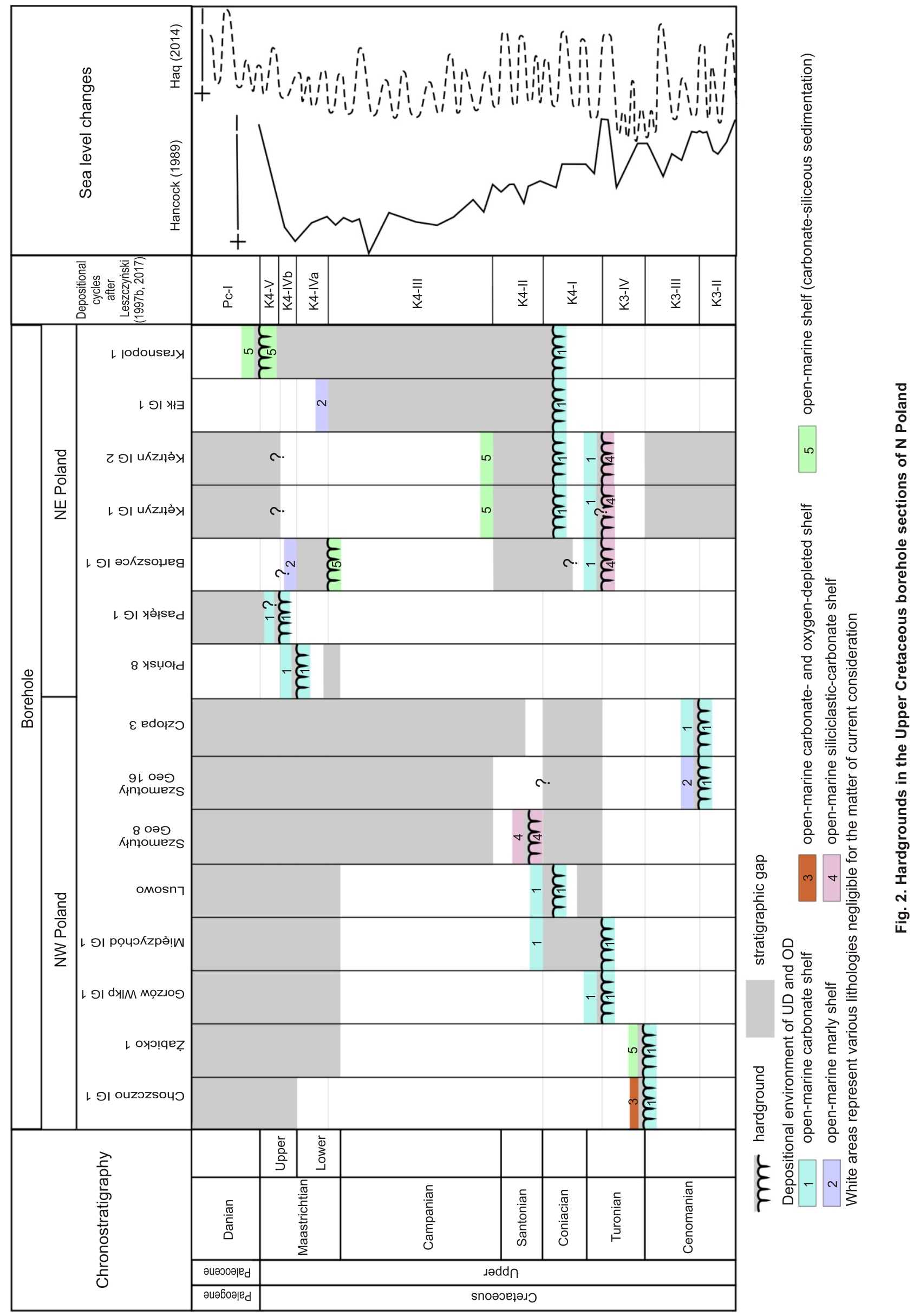



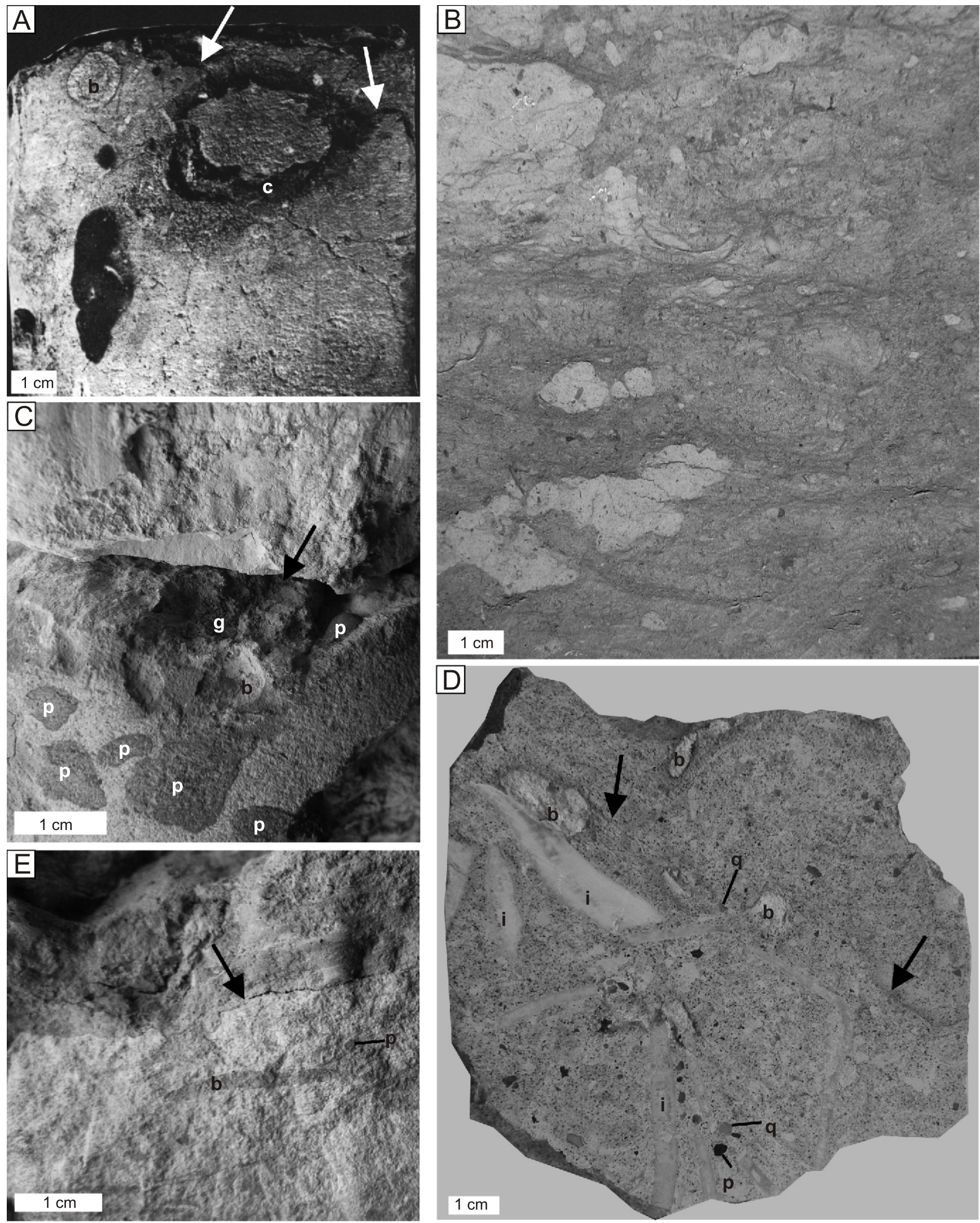

\section{Fig. 3. Examples of discontinuity surfaces in drill cores from $\mathbf{N}$ Poland}

A - Gorzów Wielkopolski IG 1, depth 652.4 m, K3-IV/K4-I: hardground - burrow beneath the hardground surface (b) and a marly limestone-filled cavern (c); B - UD: organogenic/organodetrital limestone, open-marine carbonate shelf (the most common UD sedimentary environment), depth $\sim 653.0 \mathrm{~m}$ (polished surface), K3-IV; C - Kętrzyn IG 2, depth $598.0 \mathrm{~m}$, K3-IV/K4-I: hardground - numerous phosphatic nodules ( $p$ ), burrow/boring filled with white chalk (b), and glauconite encrustation on the hardground surface (g); D - Bartoszyce IG 1, depth $422.1 \mathrm{~m}$ (polished surface, Geological Museum PGI-NRI, Warsaw, coll. M. Jaskowiak), K3-IV/K4-I: ?composite hardground - borings (b), fragments of thick-shelled inoceramids (i), quartz grains (q), and small phosphatic nodules (p); E - Olsztyn IG 1, depth 632.1 m, K4-I/K4-II: discontinuity surface - burrow (b) and a small phosphatic nodule (p); DS surfaces are arrowed; photo A by M. Jaskowiak-Schoeneichowa, photos B, C, D and E by K. Leszczyński 


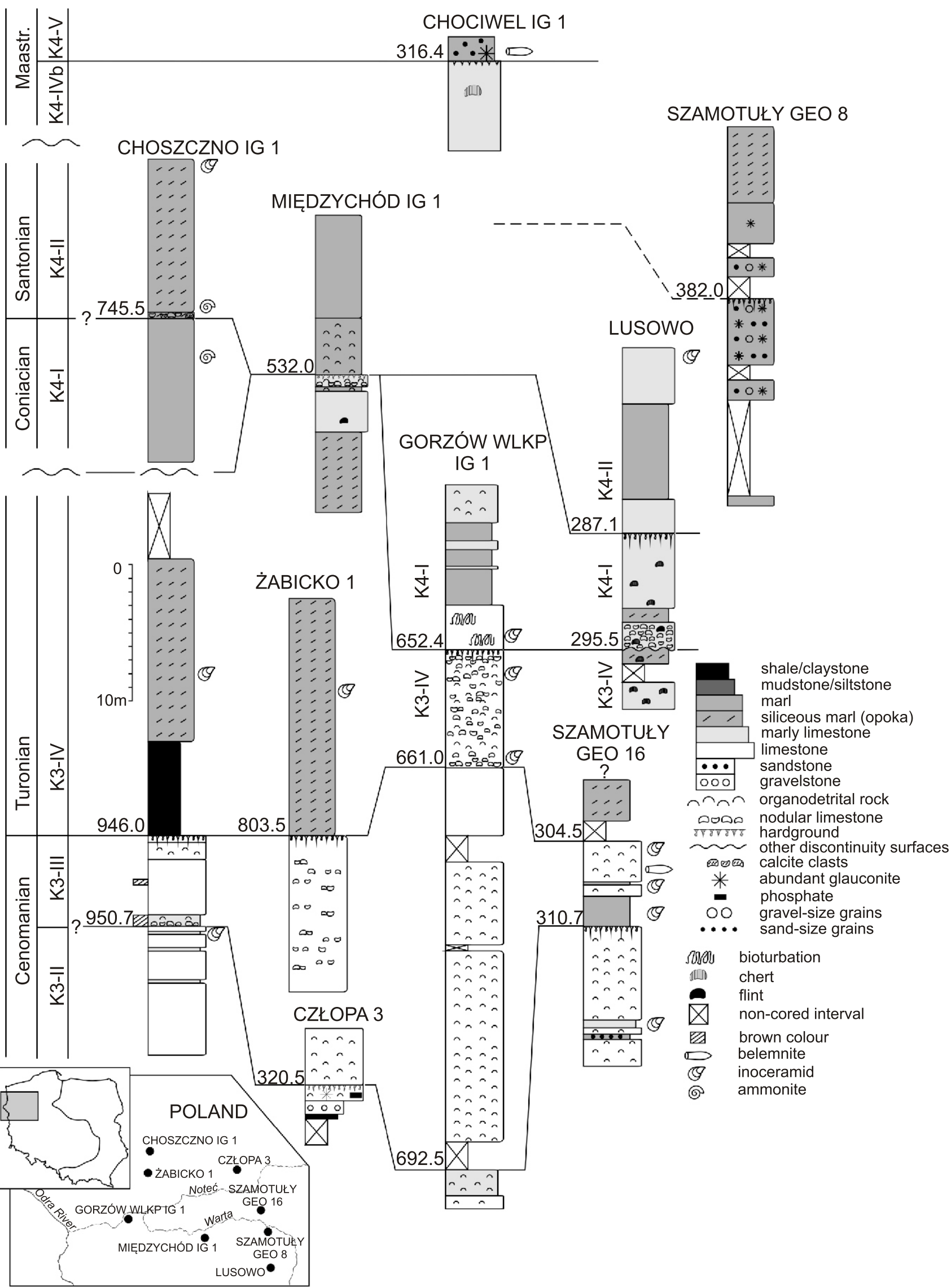

Fig. 4. Correlation of hardgrounds in boreholes from the Szczecin Trough and the Gorzów Block 

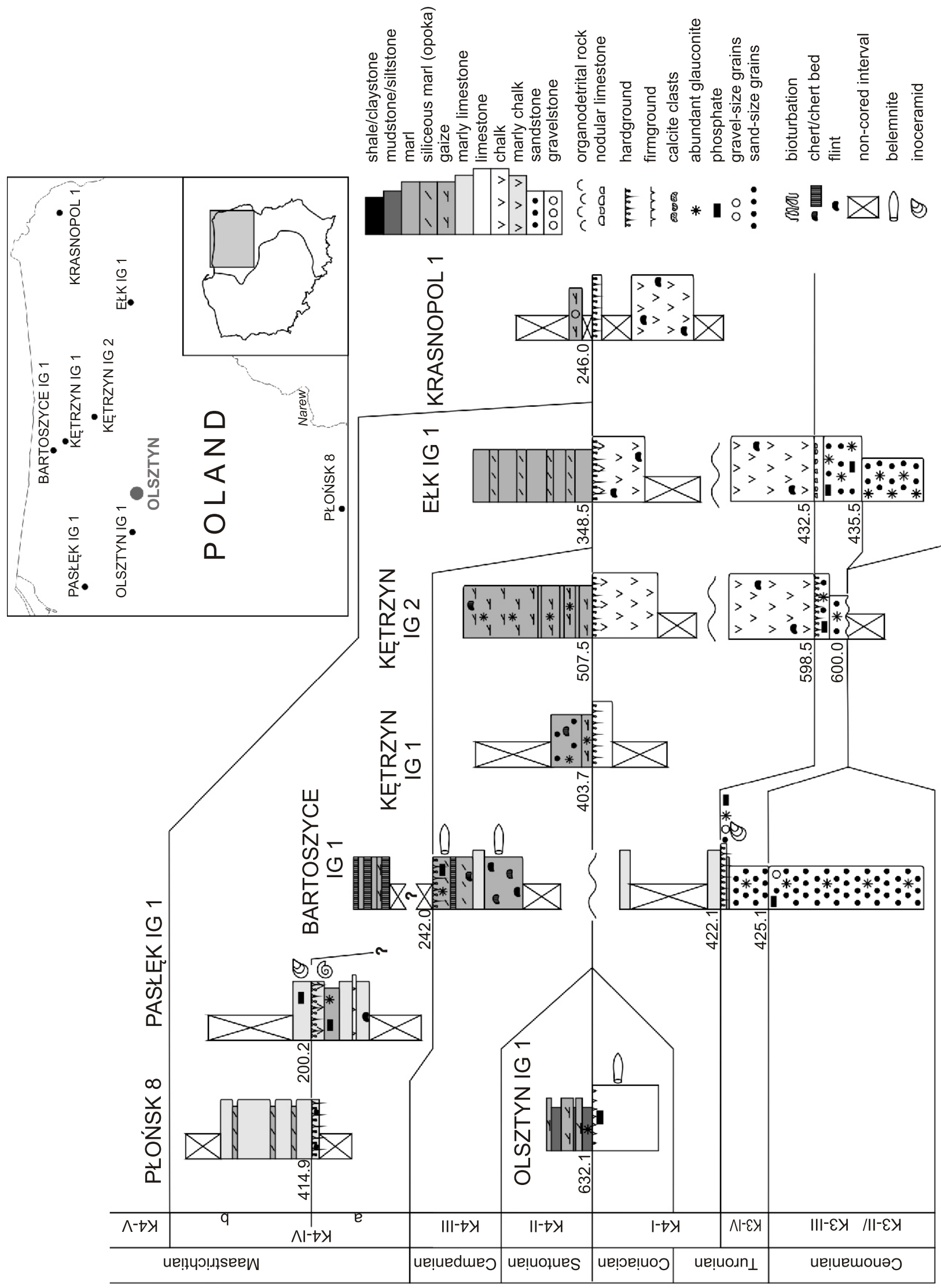

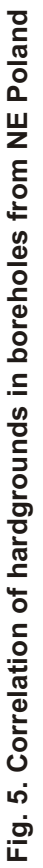

Ẽ 
with highly calcareous sandstone, opoka, sandy and sandyglauconitic limestone, and cherty gaize.

All the environments in which the discontinuity surfaces have been identified represent open-marine shelf, but with varying proportions between carbonates and fine clastics, and a varying degree of silicification, so that the following sub-environments can be distinguished (Fig. 2): (1) open-marine carbonate shelf, (2) open-marine marly shelf, (3) open-marine carbonate- and oxygen-depleted shelf, (4) open-marine siliciclastic-carbonate shelf, and (5) open-marine shelf with carbonate-siliceous sedimentation (opoka and gaize).

Discontinuity surfaces (including hardgrounds) are used for correlations between various regions of the Cretaceous sedimentary basins of Poland and elsewhere in Europe. In the Cenomanian through Maastrichtian sections, a number of hardgrounds have been found in southern Poland and in the adjacent basins of Germany and the Czech Republic. However, the greatest frequency of hardgrounds, in both northern and southern Poland, is observed in the Turonian-Coniacian interval (e.g., Walaszczyk, 1992; Olszewska-Nejbert, 2004).

For example, a well-developed composite hardground has recently been described and analysed in detail by OlszewskaNejbert (Olszewska-Nejbert, 2004; Olszewska-Nejbert and Świerczewska-Gładysz, 2013). Initiation of the formation of this composite hardground is interpreted by those authors as corresponding with a major Mid-Late Turonian unconformity described as Sequence Boundary Tu 4 at the base of the Seugast Member Roding Formation in the Bodenwöhrer Senke (NE Bavaria), near the southwestern margin of the Bohemian Massif (Niebuhr et al., 2011), and at the erosional base of the Soest Greensand Member of the Salder Formation recognized in the Werl borehole in the southern Münsterland Cretaceous Basin (Richardt and Wilmsen, 2012). This is correlated with the latest Turonian-Coniacian Subhercynian compressional tectonic activity of the llsede Phase that significantly affected the evolution of the Kraków Swell region. The composite hardground is interpreted by Olszewska-Nejbert and Świerczewska-Gładysz (2013) as corresponding to the Late Turonian sea level drop.

The latest Turonian-Coniacian Subhercynian compressional tectonic activity of the llsede Phase has been recognized in the German and Anglo-Paris basins by uplift movements, angular discordances, sedimentary gaps, facies changes, submarine slumps, turbiditic deposition and hardgrounds (Mortimore and Pomerol, 1997; Mortimore et al., 1998). In those basins, Subhercynian tectonism created a tectonic topography that, combined with the Late Cretaceous sea level fluctuations, resulted in the formation of hardgrounds.

Moreover, in Bavaria (southern Germany), Niebuhr et al. (2012) also reported the presence of a hardground in the Turonian section, at sequence boundary Tu 5 capping the Großberg Formation dated as the Late Turonian intra-Mytiloides scupini Zone. Those authors correlate the hardground with the sequence boundary recognized by Richardt and Wilmsen (2012) in the Erwitte Formation of southern Münsterland. In England, it corresponds to a condensed hardground sequence immediately above the Hitch Wood Event (Jarvis et al., 2006) and a high Upper Turonian sequence boundary of Gale (1996). Niebuhr et al. (2012) stated that the deeper marine marls of the lower Hellkofen Formation (uppermost Turonian-Lower Coniacian), abruptly overlying the unconformity at the top of the Großberg Formation (sequence boundary Tu 5), may be related to tectonic inversion at the southwestern margin of the Bohemian Massif. This is temporarily coincident with the onset of the Late Cretaceous tectonic inversion processes also in the Mid-Polish Trough.
Wiese and Kröger (1998) recognized a hardground interpreted as marking a regressive event in the Upper Turonian succession of northern Germany (Late Turonian scupini Zone in the Lower Saxony Basin). This may be correlative approximately with the same event expressed by the hardground at the $\mathrm{K} 3 / \mathrm{K} 4$ boundary interpreted in the boreholes drilled in the Polish Lowlands.

The presence of the Upper Turonian hardground overlain by Middle Coniacian marls is reported also from the Subhercynian Cretaceous Basin (Voigt et al., 2004 and references therein).

Another example comes from the Czech Republic, where Žitt et al. (2006) describe a hardground from the Cenomanian/Lower Turonian boundary in the Cretaceous Bohemian Basin, accompanied by erosion events and condensed sedimentation intervals at this boundary.

In the Cenomanian-Turonian section, hardgrounds (especially numerous around the Cenomanian/Turonian boundary) are reported from the northeastern margin of the Holy Cross Mountains in southeastern Poland (Cieśliński, 1976; Marcinowski and Walaszczyk, 1985; Walaszczyk, 1987, 1992; Dubicka and Machalski, 2017). Walaszczyk $(1987,1992)$ reported the presence of mid-Cenomanian (DS3), Cenomanian/Turonian boundary (DS4), and top-Lower Turonian (DS5) hardground and omission surfaces, and correlated them with equivalent phenomena recorded in the Cretaceous sedimentary basins of Poland and other regions. These surfaces are accompanied by stratigraphic gaps of variable extents. The Cenomanian/Turonian boundary hardground/omission surface (DS4) is interpreted by Walszczyk (1987) in terms of both sea level changes and the effect of the boundary anoxic event (OAE2). At Annopol, Dubicka and Machalski (2017) attempted to assess to what extent the global mid-Cretaceous sea level changes can be identified within a condenced succession. Paying special attention to sedimentary discontinuities (including hardgrounds) and associated stratigraphic gaps, they concluded that all transgressive peaks and regressive troughs of the relevant portion of the British sea level curve of Hancock (1989) are recorded in the Annopol succession.

In northern Poland (Gorzów Block), the only hardgrounds recognized from near the Cenomanian/Turonian boundary are those in the Choszczno IG 1 and Żabicko boreholes (Jaskowiak-Schoeneichowa, 1978b, 1981). In the former, the hardground surface is developed on marly limestones and the OD is represented by clay shales. This hardground can also be correlated with the phenomena related to the anoxic event OAE2 and a prominent sea level fall on the curves of Hancock (1989) anf Haq (2014).

\section{SUMMARY AND CONCLUSIONS}

In the Upper Cretaceous sequence of northern Poland, hardgrounds and other prominent correlative discontinuity surfaces are fairly common features observed in the cores of boreholes drilled in the Gorzów Block and in the adjacent zone of the Szczecin Trough, in the eastern part of the Peribaltic Syneclise, and in the Mazury Elevation.

In these areas, hardgrounds have been identified and described from 15 boreholes. At the hardground surfaces, the overlying deposits (OD) represent a variety of lithologies including limestone, chalk, marl, gaize, opoka, calcareous claystone and marly sandstone. The most common UD/OD configuration of sedimentary environments is the open-marine carbonate shelf both beneath and above the discontinuity surface. The 
second most common situation is the open-marine carbonate shelf beneath and the open-marine shelf with carbonate-siliceous sedimentation above. The other configurations are: (1) open-marine siliciclastic-carbonate shelf followed by open-marine carbonate shelf, (2) open-marine carbonate shelf followed by open-marine siliciclastic-carbonate shelf, (3) open-marine carbonate shelf followed by open-marine marly shelf, (4) open-marine carbonate shelf followed by open-marine carbonate- and oxygen-depleted shelf, (5) open-marine siliciclastic-carbonate shelf both beneath and above, (6) open-marine shelf with carbonate-siliceous sedimentation followed by open-marine marly shelf, and (7) open-marine shelf with carbonate-siliceous sedimentation both beneath and above. Thus, the environmental conditions before and after the formation of the discontinuity surface were much similar in most cases. Foraminifera and abundant burrows and borings at the hardground surface indicate that the seawater was relatively well oxygenated.

The discontinuity surfaces mark the boundaries between the individual depositional cycles (K3-II/K3-III, K3-III/K3-IV, K3-IV/K4-I, K3-IV/K4-II, K4-I/K4-II (or II or IV or V), K4-III/K4-IV (or V), K4-IVa/K4-IVb, probably K4-IVb/K4-V, and K4-V/Pc-I). Apart from the last two, all the others seem to correspond to sea level falls in the curve of Hancock (1989). In NE Poland the overlying deposit is commonly significantly younger than the underlying deposit, proving a major sedimentary gap spanning various time intervals ranging from very short (spanning a fraction of a depositional cycle: Chociwel IG 1, Choszczno IG 1, Żabicko 1, Gorzów Wlkp. IG 1, Lusowo, Szamotuły Geo 8, Szamotuły Geo 16, Człopa 3, Płońsk 8, Olsztyn IG 1, Bartoszyce IG 1, Kętrzyn IG 1 - lower hardground, Kętrzyn IG 2 - lower hardground, and Krasnopol 1 - upper hardground) to long periods (comprising one or more cycles: Międzychód IG 1 - K4-I, Kętrzyn IG 1 and Kętrzyn IG 2, upper hardgrounds K4-I and part of K3-IV, Ełk IG 1 - K4-III, K4-II, K4-I and part of K3-IV, and Krasnopol 1, upper hardground - K4-IV, K4-III, K4-II, $\mathrm{K} 4-\mathrm{I}$ and part of K3-IV). This indicates relatively varied environmental conditions in some areas of the sedimentary basin in northern Poland, with periods of strong sea currents or tectonic uplifting movements, which triggered differentiation in subsidence rate between various parts of the continuously open-marine basin, followed by periods of no currents and/or relatively high subsidence rate.

Most of the hardgrounds found in the Late Cretaceous carbonate succession of NW and NE Poland developed in areas of relatively calm sedimentary conditions and are related mostly to eustatic sea level fluctuations. Such areas extended outside the axial part of the Mid-Polish Trough that was characterized in the Late Cretaceous by the greatest subsidence rate followed by tectonic inversion and strong uplift, as well as by generally more intense Subhercynian tectonic (including halotectonic) movements. However, some areas outside the trough may have also been affected by the Subhercynian tectonic phases, resulting in the formation of the discontinuity surfaces.

The development of three hardgrounds reported from the Człopa-Szamotuły tectonic zone (mid-Santonian hardground from the Szamotuły Geo 8 borehole, mid-Cenomanian hardground from the Szamotuly Geo 16 borehole, and the likely mid-Cenomanian hardground from the Człopa 3 borehole) is most probably associated with tectonic activity, although the mid-Cenomanian hardgrounds are usually linked to eustatic events (e.g., Hancock, 2004; Dubicka and Machalski, 2017). The formation of the Szamotuły Geo 8 hardground is interpreted as related strictly to the broadly understood Subhercynian tectonic movements recorded elsewhere in the European Cretaceous basins. This tectonic activity was accompanied by intense salt flow, and was coeval with the early stages of tectonic inversion of the Mid-Polish Trough and other major tectonic zones in the Polish Basin. The Szamotuły Geo 16 and Człopa 3 hardgrounds are also thought to be associated with tectonic activity; however, a combination of tectonic-eustatic factors cannot be excluded in these instances.

To conclude, the author is of the opinion that the formation of the discontinuity surfaces was related mainly to both sea level fluctuations and tectonic activity during the Subhercynian phases (including activation of salt movements). The hardgrounds around the Cenomanian/Turonian boundary may also be associated with the inhibition of carbonate production during the anoxic event at that time and the prominent sea level fall marked on the curves of Hancock (1989) and Haq (2014).

The position of the hardgrounds and other correlative discontinuity surfaces facilitates looking for any possible gaps and hiatuses in the sections of other boreholes, and paying attention to local changes in sediment distribution patterns, changing bottom currents, periods of reduced sedimentation rates and retardation or breaks in sediment input and condensation episodes during low sedimentation rates. Some of these changes were undoubtedly controlled by the peculiarity of the Cretaceous climate and its variations.

Acknowledgements. The author expresses his cordial thanks to the Reviewers Prof. M. Machalski and Prof. T. Voigt, and to the anonymous Reviewer, for their critical comments and suggestions that have significantly improved the early version of the paper. Editor-in-Chief Prof. T. Peryt is warmly acknowledged for many editorial corrections. Special thanks are due to Dr M. Jaskowiak-Schoeneichowa for making available manuscripts of Cretaceous lithological sections of historical boreholes, used in this paper.

\section{REFERENCES}

Błaszkiewicz, A, 1997. Kreda górna. Biostratygrafia. Makrofauna (in Polish). Prace Państwowego Instytutu Geologicznego, 153: 367-380.

Błaszkiewicz, A, Cieśliński, S, 1979. Works on systematization of stratigraphy of the Upper Cretaceous in Poland (except for the
Carpathians and Sudety Mts) (in Polish with English summary). Kwartalnik Geologiczny, 23 (3): 639-647.

Bromley, R.G., 1975. Trace fossils at omission surfaces. In: The Study of Trace Fossils (ed. R.W. Frey): 399-428. Springer, New York. 
Bromley, R.G., Gale, A.S., 1982. The lithostratigraphy of the English Chalk Rock. Cretaceous Research, 3: 273-306.

Cieśliński, S., 1959. The Albian and Cenomanian in the northern periphery of the Święty Krzyż Mountains (in Polish with English summary). Prace Instytutu Geologicznego, 28

Cieśliński, S., 1974. Wyniki badań makrofaunistycznych kredy górnej (in Polish). Profile Głębokich Otworów Wiertniczych Instytutu Geologicznego, 14: 190.

Cieśliński, S., 1976. Development of the Danish-Polish Trough in the Holy Cross region in the Albian, Cenomanian and Lower Turonian (in Polish with English summary). Biuletyn Instytutu Geologicznego, 295: 249-271.

Clari, P.A., Dela Pierre, F., Martire, L., 1995. Discontinues in carbonate successions: identification, interpretation and classification of some Italian examples. Sedimentary Geology, 100: 97-121.

Dadlez, R., Marek, S., Pokorski, J. eds., 1998. Palaeogeographical Atlas of the Epicontinental Permian and Mesozoic in Poland. Państwowy Instytut Geologiczny, Warszawa.

Dubicka, Z., Machalski, M., 2017. Foraminiferal record in a condensed marine succession: a case study from the Albian and Cenomanian (mid-Cretaceous) of Annopol, Poland. Geological Magazine, 154: 399-418.

Eberli, G.P., Anselmetti, F., Isern, A.R., Delius, H., 2010. Timing of changes in sea-level and currents along Miocene platforms on the Marion Plateau, Australia. SEPM Special Publication, 95 219-242.

Flügel, E., 2004. Microfacies of Carbonate Rocks. Analysis, Interpretation and Application. Springer, Berlin.

Gale, A.S., 1996. Turonian correlation and sequence stratigraphy of the Chalk in southern England. Geological Society Special Publications, 103: 177-195.

Gawor-Biedowa, E., 1972. Wyniki badań stratygraficznych i uwagi porównawcze. Stratygrafia mikropaleontologiczna kredy górne w profilu Międzychód (in Polish). Profile Głębokich Otworów Wiertniczych Instytutu Geologicznego, 2: 143-150.

Gawor-Biedowa, E., 1974. Wyniki badań mikrofaunistycznych kredy górnej (in Polish). Profile Głębokich Otworów Wiertniczych Instytutu Geologicznego, 14: 190-200.

Gawor-Biedowa, E., 1978. Wyniki badań stratygraficznych litologicznych (in Polish). Mikrofauna osadów kredy górnej. Profile Głębokich Otworów Wiertniczych Instytutu Geologicznego, 43: 74-83.

Gawor-Biedowa, E., 2014a. Biostratygrafia kredy górnej na podstawie otwornic (in Polish). Profile Głębokich Otworów Wiertniczych Państwowego Instytutu Geologicznego, 138: $136-138$.

Gawor-Biedowa, E., 2014b. Biostratygrafia utworów albu górnego kredy górnej na podstawie otwornic (in Polish). Profile Głębokich Otworów Wiertniczych Państwowego Instytutu Geologicznego, 141: 235-238.

Goldring, R., Kaźmierczak, J., 1974. Ecological succession in intraformational hardground formation. Palaeontology, 17 949-962.

Grigelis, A., Leszczyński, K., 1998. Cretaceous. In: Structural Evolution of the Permian-Mesozoic Complex of Northeastern Poland, Lithuania and Adjacent Baltic Areas (eds. S. Marek and A. Grigelis). Polish Geological Institute, Warsaw.

Hancock, J.M., 1989. Sea-level changes in the British region during the Late Cretaceous. Proceedings of the Geologists' Association, 100: 565-594.

Hancock, J.M., 2004. The mid-Cretaceous eustatic low. Acta Geologica Polonica, 54: 611-627.

Haq, B.U., 2014. Cretaceous eustasy revisited. Global and Planetary Change, 113: 44-58.

Herring, E., Nestler, H., Frenzel, P., Reich, M., 1996. Discontinuity surfaces in the high Upper-Cretaceous of the Northeastern Germany and their reflection by fossil associations. Göttingen Arbeiten für Geologie und Paläontologie, 3: 107-111.
Hilbrecht, H., Dahmer, D.D., 1994. Sediment dynamics during the Cenomanian-Turonian (Cretaceous) oceanic anoxic event in Northwestern Germany. Facies, 30: 63-84.

Ineson, J.R., Buchardt, B., Lassen, S., Rasmussen, J.A., Schiřler, P., Schovsbo, N.H., Sheldon, E., Surlyk, F., 2006 Stratigraphy and palaeoceanography of upper Maastrichtian chalks, southern Danish Central Graben. Geological Survey of Denmark and Greenland Bulletin, 10: 9-12.

James, N. P., Bone, Y., 1991. Sediment dynamics of an Oligo-Miocene cool water shelf limestone, Eucla Platform, southern Australia. Sedimentology, 38: 323-342.

Jarvis, I., Gale, A.S., Jekyns, H.C., Pearce, M., 2006. Secular variation in Late Cretaceous carbon isotopes: a new $\delta^{13} \mathrm{C}$ carbonate reference curve for the Cenomanian-Campanian (99.6-70.6 Ma). Geological Magazine, 143: 561-608.

Jaskowiak-Schoeneichowa, M., 1972. Wyniki badań stratygraficznych i uwagi porównawcze. Kreda górna (in Polish). Profile Głebokich Otworów Wiertniczych Instytutu Geologicznego, 2: 135-143.

Jaskowiak-Schoeneichowa, M., 1973. Wyniki badań stratygraficznych i litologicznych. Kreda (in Polish). Uwagi stratygraficzne. Profile Głębokich Otworów Wiertniczych Instytutu Geologicznego, 9: 131-138.

Jaskowiak-Schoeneichowa, M., 1974. Wyniki badań stratygraficznych i litologicznych. Kreda górna (in Polish). Profile Głębokich Otworów Wiertniczych Instytutu Geologicznego, 14: 182-190.

Jaskowiak-Schoeneichowa, M., 1978a. Wyniki badań stratygraficznych i litologicznych. Kreda górna (in Polish). Profile Głębokich Otworów Wiertniczych Instytutu Geologicznego, 39: 161-170.

Jaskowiak-Schoeneichowa, M., 1978b. Wyniki badań stratygraficznych i litologicznych. Kreda górna (in Polish). Profile Głębokich Otworów Wiertniczych Instytutu Geologicznego, 43: 64-74.

Jaskowiak-Schoeneichowa, M. ed., 1979. The geological structure of the Szczecin Trough and Gorzów Block (in Polish with English summary). Prace Instytutu Geologicznego, 96.

Jaskowiak-Schoeneichowa, M., 1981. Upper Cretaceous sedimentation and stratigraphy in north-western Poland (in Polish with English summary). Prace Instytutu Geologicznego, 98.

Jaskowiak-Schoeneichowa, M., Krassowska, A., 1983. Upper Cretaceous (in Polish with English summary). Prace Instytutu Geologicznego, 103: 177-197.

Jaskowiak-Schoeneichowa, M., Leszczyński, K., 2014. Profil kredy w otworze Gorzów Wielkopolski IG 1 - typowy przykład rozwoju późnokredowej sekwencji węglanowej na obszarze bloku Gorzowa. Profile Głębokich Otworów Wiertniczych Państwowego Instytutu Geologicznego, 141: 229-135.

Jones, B., Desrochers, A., 1992. Shallow platform carbonates. In: Facies Models - Response to Sea Level Change (eds. R.G Walker and N.P. James). Geological Association of Canada: 277-301.

Karnkowski, P.H., 2010. Geology, origin and evolution of the Gorzów Block (NW Poland) (in Polish with English summary). Przegląd Geologiczny, 58: 680-688.

Kennedy, W.J., Garrison, R.E., 1975. Morphology and genesis of nodular chalks and hardgrounds in the Upper Cretaceous of southern England. Sedimentology, 22: 311-386.

Krassowska, A., 1973. Alb górny, kreda górna i paleocen (in Polish). Profile Głębokich Otworów Wiertniczych Instytutu Geologicznego, 4: 165-182.

Krassowska, A., 1986. The Upper Cretaceous and Lower Paleocene in the vicinities of Lublin (in Polish with English summary). Kwartalnik Geologiczny, 30 (3/4): 559-574.

Krassowska, A., 1997. Kreda górna. Sedymentacja, paleogeografia i paleotektonika (in Polish). Prace Państwowego Instytutu Geologicznego, 153: 386-402. 
Krzywiec, P., 2006. Structural inversion of the Pomeranian and Kuiavian segments of the Mid-Polish Trough - lateral variations in timing and structural style. Geological Quarterly, 50 (1): 151-168.

Krzywiec, P., Gutowski, J., Walaszczyk, I., Wróbel, G., Wybraniec, S., 2009. Tectonostratigraphic model of the Late Cretaceous inversion along the Nowe Miasto-Zawichost Fault Zone, SE Mid-Polish Trough. Geological Quarterly, 53 (1): 27-48

Lehrmann, D.J., Goldhammer, R.K., 1999. Secular variation in parasequence and facies stacking patterns of platform carbonates: a guide to application of stacking pattern analysis in strata of diverse ages and settings. SEPM Special Publication, 63: 187-225.

Leszczyński, K., 1997a. The Lower Cretaceous depositional architecture and sedimentary cyclicity in the Mid-Polish Trough. Kwartalnik Geologiczny, 41 (4): 509-520.

Leszczyński, K., 1997b. The Upper Cretaceous carbonate-dominated sequences of the Polish Lowlands. Geological Quarterly, 41 (4): 521-532.

Leszczyński, K., 2000. The Late Cretaceous sedimentation and subsidence south-west of the Kłodawa Salt Diapir, central Poland. Geological Quarterly, 44 (2): 167-174.

Leszczyński, K., 2002a. The Cretaceous evolution of the Ponętów-Wartkowice Zone (in Polish with English summary). Prace Państwowego Instytutu Geologicznego, 176.

Leszczyński, K., 2002b. The Late Cretaceous inversion and salt tectonics in the Koszalin-Chojnice and Drawno-Człopa-Szamotuły Zones, Pomeranian sector of the Mid-Polish Trough. Geological Quarterly, 46 (3): 347-362.

Leszczyński, K., 2010. Lithofacies evolution of the Late Cretaceous basin in the Polish Lowlands (in Polish with English summary). Biuletyn Państwowego Instytutu Geologicznego, 443: 33-54.

Leszczyński, K., 2012. The internal geometry and lithofacies pattern of the Upper Cretaceous-Danian sequence in the Polish Lowlands. Geological Quarterly, 56 (2): 363-386.

Leszczyński, K., 2014. Sukcesja silikoklastycznych, węglanowych i krzemionkowo-węglanowych utworów kredy górnej w otworach Kętrzyn IG 1 i Kętrzyn IG 2 (in Polish). Profile Głębokich Otworów Wiertniczych Państwowego Instytutu Geologicznego, 138: 131-136.

Leszczyński, K., 2017. Evolution of the Nasielsk-Dębe Graben (eastern central Poland) during Cretaceous times (in Polish with English summary). Biuletyn Państwowego Instytutu Geologicznego (submitted for publication).

Lykke-Andersen, H., Surlyk, F., 2004. The Cretaceous-Palaeogene boundary at Stevns Klint, Denmark: inversion tectonics or sea-floor topography? Journal of the Geological Society, 161: 343-352.

Marcinowski, R., 1974. The transgressive Cretaceous (Upper Albian through Turonian) deposits of the Polish Jura Chain. Acta Geologica Polonica, 24: 117-217.

Marcinowski, R., Walaszczyk, I., 1985. Middle Cretaceous deposits and biostratigraphy of the Annopol section, Central Polish Uplands. Österreichische Akademie der Wissenschaft, Schriftenreihe der Erdwissenschaftlichen Komissionen, 7: 27-41.

Mortimore, R., Pomerol, B., 1997. Upper Cretaceous tectonic phases and end Cretaceous inversion in the Chalk of the Anglo-Paris Basin. Proceedings of the Geologists' Association, 108: 231-255.

Mortimore, R.N., Wood, C.J., Pomerol, B., Ernst, G., 1998. Dating the phases of the Subhercynian tectonic epoch: Late Cretaceous tectonics and eustatics in the Cretaceous basins of northern Germany compared with the Anglo-Paris Basin. Zentralblatt für Geologie und Paläontologie, 1: 1349-1401.

Niebuhr, B., Wilmsen, M., Chellouche, P., Richardt, N., Pürner, T., 2011. Stratigraphy and facies of the Turonian (Upper Creta- ceous) Roding Formation at the south western margin of the Bohe mian Massif (southern Germany, Bavaria). Zeitschrift der Deutschen Gesellschaft für Geowissenschaften, 62: 295-316.

Niebuhr, B., Richardt, N., Wilmsen, M., 2012. Facies and integrated stratigraphy of the Upper Turonian (Upper Cretaceous) Großberg Formation south of Regensburg (Bavaria, southern Germany). Acta Geologica Polonica, 62: 595-615.

Olszewska-Nejbert, D., 2004. Development of the Turonian/Coniacian hardground boundary in the Cracow Swell area (Wielkanoc quarry, Southern Poland). Geological Quarterly, 48 (2): 159-170.

Olszewska-Nejbert, D., Świerczewska-Gładysz, E., 2013. Facies and sedimentation of Coniacian deposits of the Kraków Swell in the Wielkanoc area (southern Poland). Geological Quarterly, 57 (1): 1-16.

Owen, D., 1996. Interbasinal correlation of the Cenomanian Stage testing the lateral continuity of sequence boundaries. Geological Society Special Publications, 104.

Pandey, D.K., Sha, J., Choudhary, S., 2010. Sedimentary cycles in the Callovian-Oxfordian of the Jaisalmer Basin, Rajasthan, western India. Volumina Jurassica, 8: 131-162.

Peryt, D., 1983. Mid-Cretaceous microbiostratigraphy and foraminifers of the NE Mesozoic margin of the Holy Cross Mts., Central Poland. Acta Palaeontologica Polonica, 28: 417-466.

Prauss, M.L., 2006. The Cenomanian-Turonian Boundary Event (CTBE) at Wunstorf, north-west Germany, as reflected by marine palynology. Cretaceous Research, 27: 872-886.

Richardt, N., Wilmsen, M., 2012. Lower Upper Cretaceous standard section of the southern Münsterland (NW Germany): carbon stable-isotopes and sequence stratigraphy. Newsletters on Stratigraphy, 45: 1-24.

Seilacher, A., 1981. Towards an evolutionary stratigraphy. Concepts and methods in paleontology. Acta Geologica Hispanica, 16: $39-44$

Surlyk, F., Lykke-Andersen, H., 2007. Contourite drifts, moats and channels in the upper Cretaceous chalk of the Danish Basin. Sedimentology, 54: 405-422.

Vejbaek, O.V., Andersen, C., Dusar, M., Herngreen, G.F.W., Krabbe, H., Leszczyński, K., Lott, G.K., Mutterlose, J., Van Der Molen, A.S., 2010. Cretaceous. In: Petroleum Geological Atlas of the Southern Permian Basin Area (eds. J.C. Doornenbal and A.G. Stevenson): EAGE Publications b.v. (Houten): 195-209.

Voigt, T., Eynatten, H. Von, Franzke, H.-J., 2004. Late Cretaceous unconformities in the Subhercynian Cretaceous Basin (Germany). Acta Geologica Polonica, 54: 673-694.

Voigt, S., Wagreich, M., Surlyk, F., Walaszczyk, I., Ulicny, D., Cech, S., Voigt, T., Wiese, F., Wilmsen, M., Niebuhr, B., Reich, M., Funk, H., Michalik, J., Jagt, J.W.M., Felder, P.J., Schulp, A,S., 2008. Cretaceous. The Geology of Central Europe (ed. T. McCann), 2: 923-997. London, Geological Society.

Wagner, R., Leszczyński, K., Pokorski, J., Gumulak, K., 2002. Paleotectonic cross-sections through the Mid-Polish Trough. Geological Quarterly, 46 (3): 293-306.

Walaszczyk, I., 1987. Mid-Cretaceous events at the marginal part of the Central European Basin (Annopol-on-Vistula section, Central Poland). Acta Geologica Polonica, 37: 61-74.

Walaszczyk, I., 1992. Turonian through Santonian deposits of the Central Polish Uplands; their facies development, inoceramid paleontology and stratigraphy. Acta Geologica Polonica, 42: $1-122$

Wiese, F., Kröger, B., 1998. Evidence for a shallowing event in the Upper Turonian (Cretaceous) Mytiloides scupini Zone of northern Germany. Acta Geologica Polonica, 48, 265-284.

Wilmsen, M., 2003. Sequence stratigraphy and palaeoceanography of the Cenomanian Stage in northern Germany. Cretaceous Research, 24: 525-568. 
Wilson, M.A., Palmer, T.J., 1992. Hardgrounds and hardground faunas. University of Wales, Aberystwyth, Institute of Earth Studies Publications, 9: 1-131.

Witwicka, E., 1973. Wyniki badań stratygraficznych i litologicznych. Kreda. Mikrofauna w osadach kredy (in Polish). Profile Głębokich Otworów Wiertniczych Instytutu Geologicznego, 9: 138-141.

Witzke, B.J., Bunker, B.J., 1996. Relative sea-level changes during Middle Ordovician through Mississippian deposition in the lowa area, North American craton. GSA Special Paper, 306: 307-330.

Znosko, J., 1998. Tectonic Atlas of Poland. Państwowy Instytut Geologiczny, Warszawa.

Žítt, J., Vodrážka, R., Hradecká, L., Svobodová, M., Zágoršek, K., 2006. Late Cretaceous environments and communities as recorded at Chrtníky (Bohemian Cretaceous Basin, Czech Republic). Bulletin of Geosciences, 81: 43-79. 